Article

\title{
Landslide Susceptibility Mapping and Assessment Using Geospatial Platforms and Weights of Evidence (WoE) Method in the Indian Himalayan Region: Recent Developments, Gaps, and Future Directions
}

\author{
Amit Kumar Batar ${ }^{1,2, *(D)}$ and Teiji Watanabe ${ }^{3}$ (D) \\ 1 Field Science Center for Northern Biosphere, Hokkaido University, Sapporo, Hokkaido 060-0809, Japan \\ 2 Graduate School of Environmental Science, Hokkaido University, Sapporo, Hokkaido 060-0810, Japan \\ 3 Faculty of Environmental Earth Science, Hokkaido University, Sapporo, Hokkaido 060-0810, Japan; \\ teiwata@mac.com \\ * Correspondence: amitbatar@fsc.hokudai.ac.jp; Tel.: + 81-70-7543-7582
}

Citation: Batar, A.K.; Watanabe, T. Landslide Susceptibility Mapping and Assessment Using Geospatial Platforms and Weights of Evidence (WoE) Method in the Indian

Himalayan Region: Recent

Developments, Gaps, and Future Directions. ISPRS Int. J. Geo-Inf. 2021, 10, 114. https://doi.org/10.3390/ ijgi10030114

Academic Editors: Wolfgang Kainz and Dean Kyne

Received: 7 December 2020

Accepted: 24 February 2021

Published: 27 February 2021

Publisher's Note: MDPI stays neutral with regard to jurisdictional claims in published maps and institutional affiliations.

Copyright: (C) 2021 by the authors. Licensee MDPI, Basel, Switzerland. This article is an open access article distributed under the terms and conditions of the Creative Commons Attribution (CC BY) license (https:/ / creativecommons.org/licenses/by/ $4.0 /)$.
Abstract: The Himalayan region and hilly areas face severe challenges due to landslide occurrences during the rainy seasons in India, and the study area, i.e., the Rudraprayag district, is no exception. However, the landslide related database and research are still inadequate in these landslide-prone areas. The main purpose of this study is: (1) to prepare the multi-temporal landslide inventory map using geospatial platforms in the data-scarce environment; (2) to evaluate the landslide susceptibility map using weights of evidence (WoE) method in the Geographical Information System (GIS) environment at the district level; and (3) to provide a comprehensive understanding of recent developments, gaps, and future directions related to landslide inventory, susceptibility mapping, and risk assessment in the Indian context. Firstly, 293 landslides polygon were manually digitized using the BHUVAN (Indian earth observation visualization) and Google Earth ${ }^{\circledR}$ from 2011 to 2013. Secondly, a total of 14 landslide causative factors viz. geology, geomorphology, soil type, soil depth, slope angle, slope aspect, relative relief, distance to faults, distance to thrusts, distance to lineaments, distance to streams, distance to roads, land use/cover, and altitude zones were selected based on the previous study. Then, the WoE method was applied to assign the weights for each class of causative factors to obtain a landslide susceptibility map. Afterward, the final landslide susceptibility map was divided into five susceptibility classes (very high, high, medium, low, and very low classes). Later, the validation of the landslide susceptibility map was checked against randomly selected landslides using IDRISI SELVA 17.0 software. Our study results show that medium to very high landslide susceptibilities had occurred in the non-forest areas, mainly scrubland, pastureland, and barren land. The results show that medium to very high landslide susceptibilities areas are in the upper catchment areas of the Mandakini river and adjacent to the National Highways (107 and 07). The results also show that landslide susceptibility is high in high relative relief areas and shallow soil, near thrusts and faults, and on southeast, south, and west-facing steep slopes. The WoE method achieved a prediction accuracy of $85.7 \%$, indicating good accuracy of the model. Thus, this landslide susceptibility map could help the local governments in landslide hazard mitigation, land use planning, and landscape protection.

Keywords: landslide susceptibility; landslide inventory; weights of evidence (WoE); web-based platforms; Google Earth ${ }^{\circledR}$; BHUVAN; remote sensing; geographical information system (GIS); Rudraprayag district; Indian Himalayan Region (IHR)

\section{Introduction}

Landslides are among the most dangerous and frequently occurring natural hazards in many hilly or mountainous terrains, which often occur without warning and cause the 
loss of life and property. The occurrence of landslides mainly depends on the local terrain condition and control by geological and geomorphological processes. However, landslides can be triggered on unstable slopes by external factors such as heavy rainfall, earthquakes, flooding, snow melting, stream erosion, change in ground water-level, volcanic eruption, or any combination of these natural factors [1-5]. The previous studies also indicated that the frequency and the magnitude of landslides are increased in many hilly or mountainous areas due to continuous disturbance by human activities such as the expansion of the built-up and agricultural area, deforestation, clear-cutting, shifting agriculture, and poor road construction [6-10]. Therefore, the frequency, magnitude, and volume of landslides are expected to increase by both internal and external factors. Moreover, the frequency and magnitude of landslides are further increasing due to climatic extremes in fragile hilly or mountainous areas. Despite this fact, many countries worldwide are facing large-scale human tragedies, material damages, and economic losses by landslide events [11-13]. It is also essential to recognize that the spatial distribution, frequency, magnitude, and volume of landslides negatively impact the natural landscape. The landslides can cause tree losses, forest fragmentation, and land-use/land-cover changes, further enhancing slope instability or slope failure [14-16]. The landslide can also affect the water quality of the river channels and reservoirs by transporting significant sediment amounts, especially in landslide-prone areas [17]. However, the role and effects of landslides on the natural landscape are often overlooked, and less consideration has been given to landslide impact and disturbance on the natural landscape. [18,19]. Therefore, to mitigate the risk of landslide occurrences in unstable slopes and evaluate the short and long-term adverse effects of landslides on the natural landscape, an interdisciplinary approach is needed.

The Himalayas are among the most unstable and fragile mountain areas in the world [20]. The Himalayan region and hilly areas in India are highly prone to landslides, i.e., over $12 \%$ of India's land area is prone to landslide hazard, including northeast and northwest Himalaya, western Ghats, and Konkan hills (Tamil Nadu, Kerala, Karnataka, Goa, and Maharashtra) and in eastern Ghats of Aruku area in Andhra Pradesh [21]. In the Indian Himalayan Region (IHR), landslide frequently occurs due to internal factors such as lithology setting, higher altitude, steep slope, fragile soil, high relief, and groundwater. However, the previous studies also emphasize that external factors such as heavy rainfall, earthquakes, and anthropogenic activities such as deforestation, shifting agriculture, road construction, and agriculture expansion further increased landslides in many potentially unstable slope areas [22-26]. The recently updated global landslide catalog (2007-2018) available on NASA's open data portal (https: / / data.nasa.gov / browse (accessed on $2 \mathrm{Au}-$ gust 2020)) indicated that the Indian Himalayas is a hotspot area of landslides that were mainly triggered by rainfall. However, such global efforts to prepare the landslide database are limited and goal-oriented (earthquake and rainfall-induced landslides), which do not provide detailed information of landslide types and volume (length, width, and depth) of landslides. In addition, the point data of landslide may not be helpful to understand the effects on ecology and hydrology system. Therefore, the development of multi-temporal landslide inventory data is essential for disaster management and landscape protection, especially in the biodiversity-rich region like the Indian Himalayas.

Moreover, the fragile nature of the Indian Himalayas and continuous human disturbance into the natural landscape can increase slope instability and lead to multiple hazards, which may be further influenced by climate change or extremes. However, the previous studies were considered separately on multiple natural hazards for disaster risk reduction, which may have produced biased results related to risk assessment. It is clear now that one hazard can influence other hazards. As a result, multiple hazards may affect the same natural landscape with serious environmental problems in mountainous terrain or hilly areas in India. Therefore, to tackle multiple hazards and mitigate disaster risk in the Indian Himalaya Region (IHR), a holistic approach is needed. 


\subsection{Literature Review of Landslide Susceptibility Mapping and Assesment: Global Context}

We review the commonly used methods for landslide susceptibility mapping and assessments and further discuss their limitations and advantages in this section. Many researchers applied different approaches to assess and evaluate landslide susceptibility, which can be broadly classified into three categories:

The qualitative approach (heuristic methods), which is a direct or semi-direct estimation to assign weights to the relative impact of causative factors on the instability of slopes by the logical judgment of expert. The heuristic methods are applicable when the relationship between landslide hazard and the importance of intrinsic variables are known [26-28].

The deterministic approach is an indirect estimation of slope instability analysis based upon engineering principles and expresses susceptibility or hazard degree by the factor of safety. The deterministic approaches are known as physical-based models or geotechnical models and applicable when the ground conditions across a study area are relatively homogeneous [29-31].

The quantitative approach (statistical methods) is an indirect estimation of slope instability based on the importance or role of various geo-environmental factors that cause landslides and determined by relationships with landslides [32-35].

The previous work indicated that the heuristic and deterministic approaches are influenced by limitations of data availability, quality, and techniques and can yield biased results without expert knowledge $[11,12]$. That is why the heuristic and deterministic approaches have uncertainties to produce a significant landslide susceptibility map and might yield biased results in a data-scarce environment. Since the 1990s, the various deterministic approaches (computer-assisted physical base models) are available for predicting slope instability using specific landslide, digital elevation model (DEM) as primary input data based upon engineering principles. These physical-based models widely applied in slope stability, triggers, failure, and slope dynamics includes Shallow Landslide Stability Model (SHALSTAB), Rainfall Intensity and Regional Slope Stability (TRIGRS), Stability Factor Method (SINMAP), Hydrological Stability Model (CHASM), Slope Morphology Model (SMORPH), Shallow Landslide Model, Dynamic Stability and Shallow Landslide Mode (iSLAM/IDSSM), Shallow Landslide Analysis Models (dSLAMs), Stability Analysis (LISA), European Hydrology System (SHETRAN), Slope Probability Analysis Model (PISA), PCRaster GIS Package-Stability Model (PROBSTAB), Slope Stability Probability Model (SSPM), Slope Stability and Water Saturation Simulation (SUSHI), Hydrological Dispersion Model (GEOtop-FS) [36-42]. However, the deterministic approach (physicalbased models) has a certain degree of uncertainty related to complicated calculation of safety factor, required detailed datasets, scale, and understanding of physical laws controlling slope instability $[43,44]$. Therefore, the results are often biased in the absence of appropriate data related to slope material and conditions, techniques, and high-resolution DEM [45]. In addition, the deterministic approaches require large volumes of detailed data derived from laboratory tests and field surveys, making them highly unsuitable for regional-scale studies and cost-effective approaches for extensive studies [35]. However, many researchers claimed that the deterministic approaches are acceptable for the groundwork of an approximate prone area zoning to produce a small-scale landslide susceptibility mapping [46,47].

In recent years, the statistical (quantitative approach) methods have been widely applied to assess landslide susceptibility or hazard map due to the advantages of the remote sensing and geographical information system (GIS) techniques [48]. The statistical (quantitative approach) methods gained importance because such methods can reduce the inherent subjectivity in selecting the input data and can be applied in small to large-scale areas $[49,50]$. The various statistical methods (broadly can classify into three types: bi-variate, multivariate, and probabilistic prediction models) have been applied and compared to test the validity and efficiency to find the best suitable model to assess landslide susceptibility mapping [51-56]. Some of the statistical methods frequently applied for landslide 
susceptibility mapping include the information value (IV) method [57], logistic regression (LR) method [57,58], fuzzy logic (FL) method [59], artificial neural network (ANN) method [60,61], frequency ratio (FR) method [62,63], Bayes' theorem based on weights of evidence (WoE) method [64,65], and bivariate statistical analysis [66,67]. The previous studies also emphasize that quantitative methods such as WoE, FR, FL, and LR can be employed in a small-scale mapping if geo-environmental factors and landslide inventory is available [68]. An excellent effort and recommendation for the landslide methodology framework was recently made to apply the quantitative approach of landslide hazard, vulnerability, and risk analysis at different spatial scales [69]. However, the availability and quality of input data and scale of the study area are critically significant to apply the proper quantitative technique for landslide susceptibility or hazard mapping. There are many efforts also made to combine empirical and physically-based models to improve the prediction capability for landslide susceptibility or hazard mapping [70].

More recently, machine learning (ML) techniques are gaining importance due to high predictive results, reproducibility, and superior performance capabilities than other statistical or knowledge-based methods. Many researchers widely applied ML techniques to find out the best suitable model to assess the landslide susceptibility mapping including neural-fuzzy [71], support vector machines (SVMs) [72,73], decision tree (DT) method [74], artificial neuronal networks (ANNs) [75], neuro-fuzzy-NF and adaptive neuro-fuzzy inference system (ANFIS) [76], generalized additive model (GAM) [77], adaBoost (AB) [78,79], random forest (RF) [80,81], naïve Bayes' (NB) [82], kernel logistic regression (KLR) [83], boosted regression tree (BRT) [84], classification and regression tree (CART) [85], general linear model (GLM) [85], multivariate adaptive regression spline (MAR Spline) model [86], maximum entropy (MaxEnt) [87], and quadratic discriminant analysis (QDA) [88]. Many researchers compared different machine learning (ML) techniques and ensemble with the statistical method to test the model performance, which can be found in the literature $[87,88]$. However, machine learning (ML) techniques are sensitive to the selection of controlling factors and still complex to apply without advanced knowledge of algorithms $[89,90]$. Therefore, to understand available ML techniques, a detailed description of algorithms is needed. In conclusion, each of these methods has advantages and disadvantages regarding the role and importance of causative factors, selection of technique, spatial scale, and data collection quality [49]. In addition, no one method or technique is accepted universally for adequate assessment of landslide susceptibility or hazards mapping. That is why landslide study is still a complicated and debatable issue to produce the accurate and useful landslide susceptibility or hazards mapping [49].

\subsection{Literature Review of Landslide Susceptibility Mapping and Assessment: Indian Context}

We summarize recent research progress and gaps in landslide susceptibility mapping and assessments in the Indian context. Since 1980, the landslide hazard zonation, vulnerability, and risk analysis related research gained importance in India. The first paper on landslide hazard zonation in India was published in the 1980s by [91,92]. For the first time, the heuristic approach was applied to evaluate landslide hazard and zonation mapping in mountainous terrain by [26]. After that, in the year 1998, under the guideline of the Bureau of Indian Standards (BIS-IS 14496, Part 2), the BIS [93] method (heuristic approach) was introduced and recommended for medium-scale landslide hazard zonation map on 1:25,000 or 50,000 scales for Indian mountainous terrain initially proposed by [33]. However, the BIS method may be challenging to carry out landslide hazard mapping in a data-scarce environment and can yield biased results without knowledge of geo-factors. In addition, this method is based upon fixed ratings or rankings of geo-factors without including landslide inventory data. Although, a few (semi) quantitative approaches attempts were made to modify BIS Code-Appraisal [94,95], and a few recommendations were suggested to improve fixed ratings of geo-factors that exist in the BIS method by inclusions of landslide inventory [96]. A few attempts were also suggested by the deterministic approach to improving landslide susceptibility or hazard mapping in India [97]. 
In the past and recently, there are many quantitative approaches, i.e., statistical and GIS-based integrated approaches, that have been proposed and applied for landslide hazard zonation or susceptibility mapping in many parts of the Himalayas and hilly areas in India [98-111]. However, very few studies attempted in detail landslide susceptibility or hazard mapping and their validation [96]. A few studies [95,96] were also attempted to compare the different quantitative techniques for better landslide hazard mapping in India. Recently, Ghosh [96] compared the BIS and the weights of the evidence (WoE) method to improve landslide susceptibility mapping in Indian mountains. The results showed that the WoE was a much better result than the BIS method. Other studies were also conducted to compare the BIS, multi-criteria analysis (MCA), and FR method in the Western Ghats of India, and the result has shown the FR method is more predictable compared to BIS and MCA [111]. Moreover, the effects of different types of landslides cannot be ignored in the Indian Himalayan region. However, very few attempts were made to address the types of landslides and their consequences on the natural environment in the Himalayan region and hilly areas in India. It is clear now that the landslide related database and research are still inadequate in these landslide-prone areas. Hence, we address the current gaps and discuss some opportunities to improve the landslide inventory, susceptibility, and risk assessment in the Indian context in Section 4.2.

\subsection{Landslide Susceptibility Mapping and Assessments: Present Study}

The Rudraprayag district of the Indian Himalayan Region (IHR) is well known for multiple-natural disasters such as landslides, earthquakes, cloudbursts, and flash floods [14,112-116]. The area in Rudraprayag district, where the Kedarnath temple (Figure 1) is situated, has already faced widespread destruction eight times by natural disasters in the past 40 years, and many people have suffered [14,112-116]. The distructive natural disasters that occurred in the past are still fresh in people's mind. These disasters have occurred near Agastmuni (2005 and 2006), Jakholi (2010), Ukhimath (2010, 2012, and 2013), and Vijaynagar (2005), which has caused losses of life and property [117]. More recently, the Mandakini river valley of Rudraprayag district and its surrounding areas were severely affected by flooding tragedies (2013), which triggered approximately 2395 landslides and widespread destruction $[14,118]$. These are a few examples of the devastation, which indicates risk (hazard, exposer, and vulnerability) by natural disasters in the Rudraprayag district.

The Himalayan region and hilly areas face severe challenges due to landslide occurrences during the rainy season in India, and the Rudraprayag district is no exception. The Rudraprayag district of the Indian Himalayan Region (IHR) is well known for multiple disasters, including landslides [14,117]. Therefore, landslide susceptibility mapping is a vital tool to identify hazardous areas and an essential basis for promoting safe human occupations, infrastructure development, and landscape protection in this landslide-prone area. It should be noted that multiple-temporal landslide inventory is necessary to prepare the effective landslide susceptibility or hazard zonation map. However, the multi-temporal landslide inventory data are lacking because of no systematic historical records [14,106]. The available landslide hazard zonation map provided by the Indian Government is too general on a given map, as discussed in detail in Section 4.2.1. The previous studies used point location of landslides for landslide hazard assessments, which may produce biased results for this study area $[119,120]$. Hence, we used geospatial platforms to prepare the landslides as a polygon for landslide susceptibility mapping and assessment in the present study. 



Figure 1. The study area (a) location map of Rudraprayag district of Uttarakhand state in the Indian Himalayan Region; and field photographs of landslide occurrences (2016/04/03) in the study area; (b) tree lost by landslide; and (c) road damaged by landslide.

The previous study suggested that the WoE method has better accuracy than the BIS method [96] and other statistical methods [110,111], as discussed previously in Section 1.2. The currently used analytical hierarchy process (APH) method for landslide susceptibility mapping by the Geological Survey of India (GSI) has uncertainty related to the ranking of geo-factors, discussed in detail in Section 4.2.1. The advantage of the WoE method is to avoid weight's subjectivity to determine the causative factors compared to the BIS $[93,94,96]$ and APH methods, which needs to be investigated. The WoE method was applied by Martha et al. $[95,104]$ at a small watershed in the Rudraprayag district, which needs further assessment. Hence, the development of a district-level susceptibility map is required towards implementing risk management plans and effectively mitigate landslide hazards. In addition, the landslide susceptibility mapping and risk assessment are fundamental components for disaster management in landslide-prone areas, especially in developing countries like India. However, landslide related database and research in these areas are still inadequate. This hampers the further analysis of landslide hazard related assessment. Therefore, taking the example of the Rudraprayag district, the main purpose of this study was: 
1. to prepare the landslide inventory map using geospatial platforms in the data-scarce environment;

2. to evaluate the landslide susceptibility map using weights of evidence (WoE) method in the Geographical Information System (GIS) environment at the district level; and

3. to provide a comprehensive understanding of recent developments, gaps, and future directions related to landslide inventory, susceptibility mapping, and risk assessment in the Indian context.

\section{Materials and Methods}

\subsection{Study Area (The Rudraprayag District)}

The study area, i.e., the Rudraprayag district, is a part of the Garhwal Himalaya division of Uttarakhand and covers about a $1936.54 \mathrm{~km}^{2}$ geographical area (Figure 1). The Rudraprayag district is under the high-risk earthquake zone because the Main Central Thrust (MCT) is passing through this area [121,122]. The Rudraprayag district is prone to multiple natural hazards such as landslides, earthquakes, and flash floods [115-117]. Rainfall-induced landslides are common in this study area. The rainfall is highly variable depending upon the altitude in this study area. The average annual rainfall is around $1220.18 \mathrm{~mm}$ in the southern part, while in the central position at Chandrapuri, the average annual rainfall is $1750.9 \mathrm{~mm}$, and in the northern part at Ukhimath, the average annual rainfall is $1995 \mathrm{~mm}$ [117]. The overall average rainfall in the Rudraprayag district is $1485 \mathrm{~mm}$. The Rudraprayag district receives most of the rainfall (70-80\% of annual precipitation) from June to September. The mean temperature in winter (December to February) varied between 8.32 to $13.15^{\circ} \mathrm{C}$ and in summer (May to July) 27.75 to $32.54{ }^{\circ} \mathrm{C}$ [117]. The upper part of the study area is protected as a Kedarnath wildlife sanctuary covering a $975 \mathrm{~km}^{2}$ area (Figure 1). Mandakini, with a catchment area of $1641.64 \mathrm{~km}^{2}$, is the principal river. In this study area, the elevation ranges from $546 \mathrm{~m}$ to $6840 \mathrm{~m}$ above mean sea level (msl), and slopes vary from gentle to very steep. Agricultural practices are mostly developed along the river and road and primary livelihood source for the local peoples [14]. Simultaneously, the study area has a significant pilgrimage site (Kedarnath Temple) where millions of devotees visit to temple every year [14]. Therefore, the pilgrimage site offers a substantial livelihood option to local people in the Rudraprayag district and its surrounding areas [14,117]. According to the data of Uttarakhand tourism, approximately 300,000 and 572,454 Indian people visited the Kedarnath temple in 2001 and 2012, respectively (https:/ / uttarakhandtourism.gov.in/ (accessed on 17 January 2021)). Therefore, the infrastructure-driven development is increasing due to increasing demand by locals and visitors, which can affect land use and land cover [14]. Most of the population (92\%) lives in rural areas, and the majority of the villages are situated along the road and river channel (Figure 1). The Rudraprayag district has a total population of 242,000 , which is low compared to another district of Uttarakhand. According to the Indian Census, the population density was 115 persons per $\mathrm{km}^{2}$ in 2001 and 119 persons per $\mathrm{km}^{2}$ in 2011.

\subsection{Data Preparation}

The data preparation for landslide susceptibility mapping divided into two groups as: (1) landslide inventory (polygon data); and (2) causative factors of landslide.

\subsubsection{Landslide Inventory (Polygon Data of Landslides)}

The multi-temporal landslide inventory is essential for understanding the relationship between past landslide occurrences and their causative factors. In this study, we applied the weights of evidence (WoE) method, which is based upon the assumption that the past is key to the future; thus, the past landslide data are necessary [123,124]. The previous studies emphasized that the point location data of landslides could ignore the size or magnitude of landslides and might yield a biased result for landslide susceptibility mapping and assessment [124]. Therefore, to reduce these uncertainties, the landslide as a polygon was used in this study. The multi-temporal landslide inventory dating was prepared 
through multiple data sources, i.e., BHUVAN (Indian earth observation visualization), a web-based geospatial platform developed by the Indian Space Research Organization (ISRO), government reports, and Google Earth ${ }^{\circledR}$ imagery. Thus, taking advantage of webbased platforms (BHUVAN and Google Earth ${ }^{\circledR}$ ), the government reports, and previous studies, we prepared multiple-temporal landslide inventory data from 2011 to 2013, along with a ground truth survey [125]. These landslides were triggered by heavy rainfall, flash flood, and cloudburst in the Rudraprayag district. At first, the landslide's location was extracted as a reference from the BHUVAN, and the government report [115-117]. Afterward, these landslide's location data were imported into Google Earth ${ }^{\circledR}$, and then the landslides were delineated using high-resolution Google Earth ${ }^{\circledR}$ imagery to prepare a multi-temporal landslide inventory in ArcGIS. Thus, we were able to use the Google Earth $^{\circledR}$ engine to extract 293 landslides as polygons from 2011 to 2013. Later, the landslide polygons were converted to raster using the vector to raster conversion tool in ArcGIS. Afterward, all landslide polygons were re-sampled in the same pixel size with the standard UTM $44 \mathrm{~N}$ zone. Figure 2 shows an example of landslides identification using the BHUVAN and Google Earth ${ }^{\circledR}$ engine.

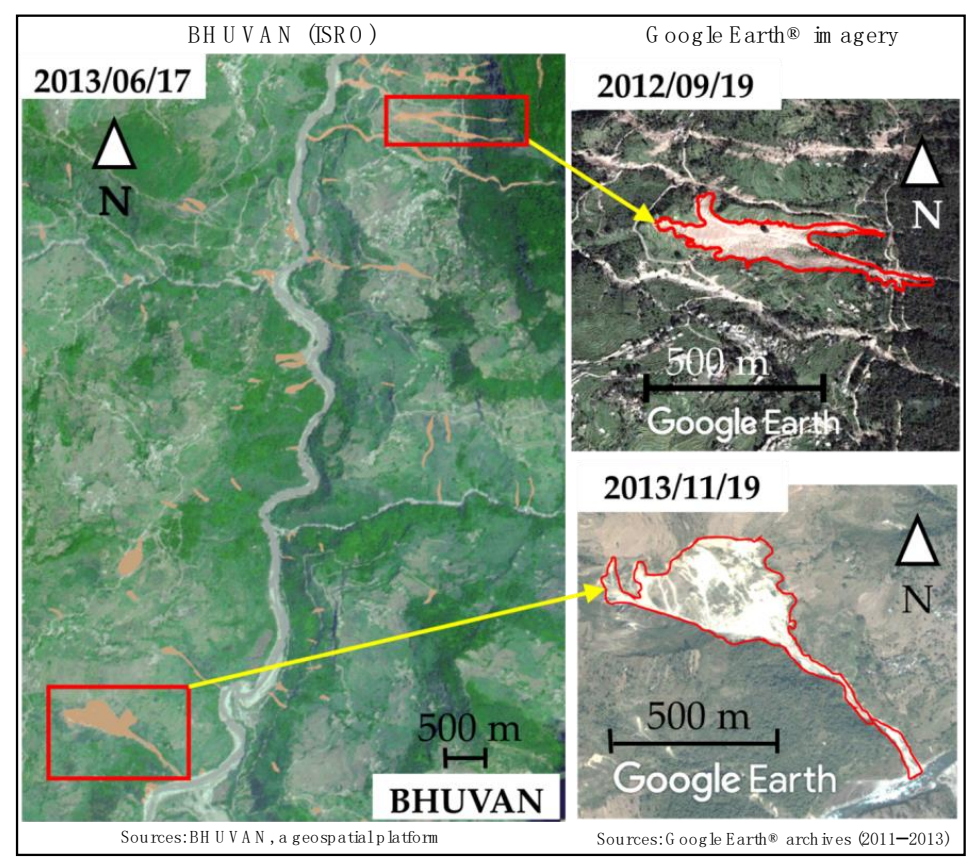

Figure 2. An example of the landslide's identification from BHUVAN (a geospatial platform) (http: //bhuvan.nrsc.gov.in (accessed on 2 August 2020)) and digitization of landslides from Google Earth $^{\circledR}$ imagery.

\subsubsection{Landslide Causative Factors}

There are no fixed guidelines for selecting the parameters that influence landslides in susceptibility mapping [126,127]. The causative factors were selected based on previous landslide studies [91-120], the scale of analysis, data availability, and fieldwork in the Rudraprayag district. At first, we reviewed the literature and government reports related to landslide susceptibility mapping in the Rudraprayag district $[95,126,127]$. After that, the most significant landslide-related spatial and attribute data, namely geology, geomorphology, soil type, soil depth, slope angle, slope aspect, relative relief, distance to faults, distance to thrusts, distance to lineaments, distance to streams, distance to roads, land use/cover, and altitude zones, were selected for this study area. We discuss the role of causative factors for landslides in detail in Sections 3.4 and 4.1.

Map layers depicting lithology, geomorphology, and major structures (thrust, fault, and lineament) were derived from the geological maps prepared by Disaster Mitigation 
Management Centre (DMMC) [117]. Topography-related layers (slope angle, slope aspect, altitude zone, relative relief, and streams network) were derived from stereoscopic Cartosat1 DEM at the 10-m resolution, which is freely available at BHUVAN (http:/ /bhuvan.nrsc. gov.in (accessed on 2 August 2020)). Roads data were extracted using a digitization tool in the BHUVAN. A map layer depicting land use/cover map (2014) was prepared using Landsat 8 Operational Land Imager (OLI) satellite data obtained from the United States Geological Survey (USGC). Soil type and depth layers were derived from Uttarakhand Soil Information.

A brief description of the preparation procedure of each data layer is provided here. The slope angle and slope aspect derived from a 10-m DEM extracted using ArcGIS. Relative relief was derived from the DEM using the zonal statistics tool of ArcGIS, wherein DEM was used as zones. Distance to streams was produced from DEM by hydrology tools in ArcGIS. Road data were digitized from the BHUVAN (http:/ / bhuvan.nrsc.gov.in (accessed on 2 August 2020)) online geospatial platform. Landsat 8 OLI satellite image was used for producing the land use/cover using a supervised classification method with maximum likelihood technique in ArcGIS. The layers of distance to streams, faults, thrusts, lineaments, and roads were calculated by the Euclidean distance system in spatial analyst tools of ArcGIS. The altitude zone map was produced in accordance with the India Meteorological Department (IMD). All data were converted to raster format with the same pixels, and each raster map was divided into several classes. Figure 3 shows the final outputs of causative factor maps.
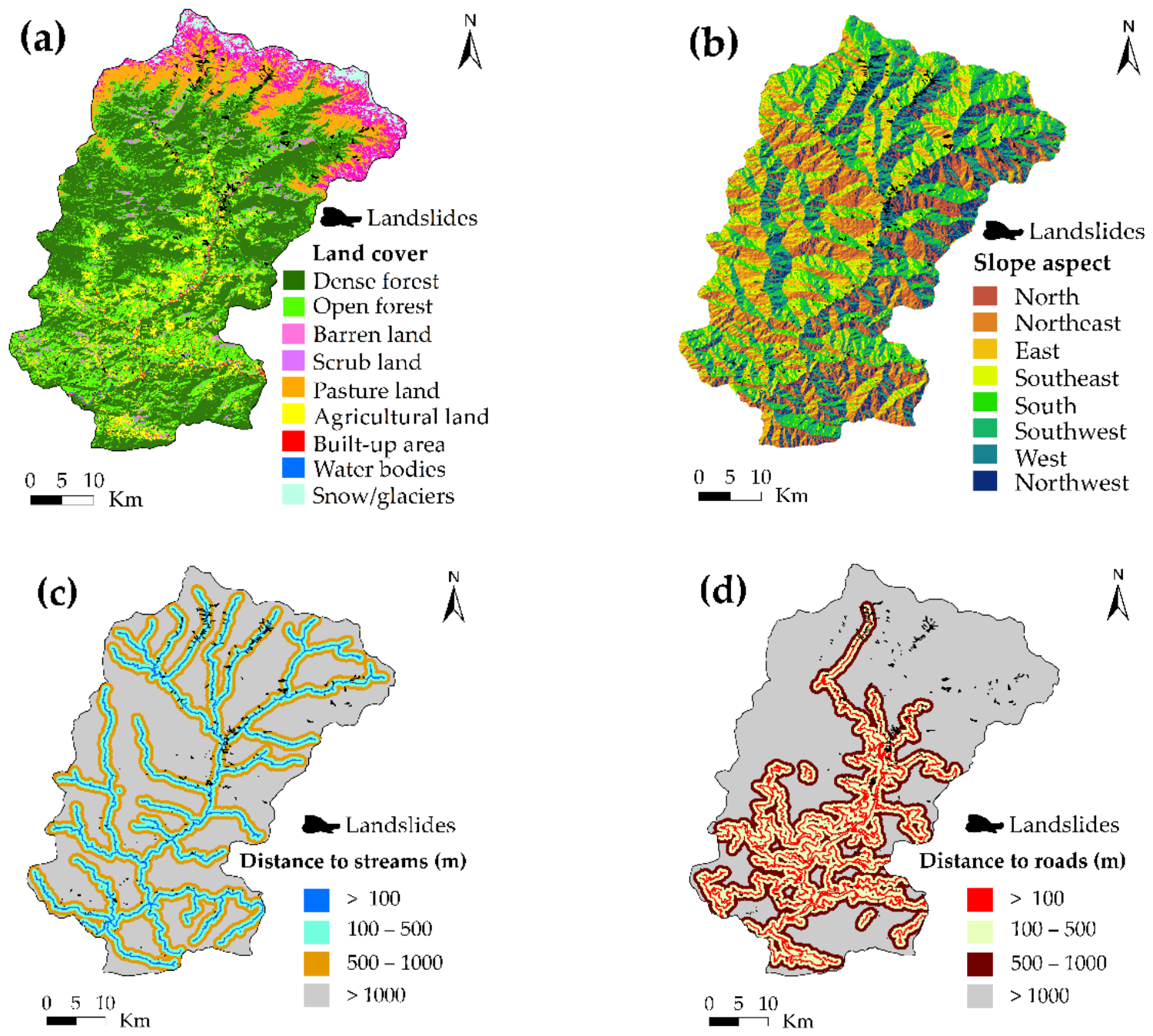

Figure 3. Cont. 

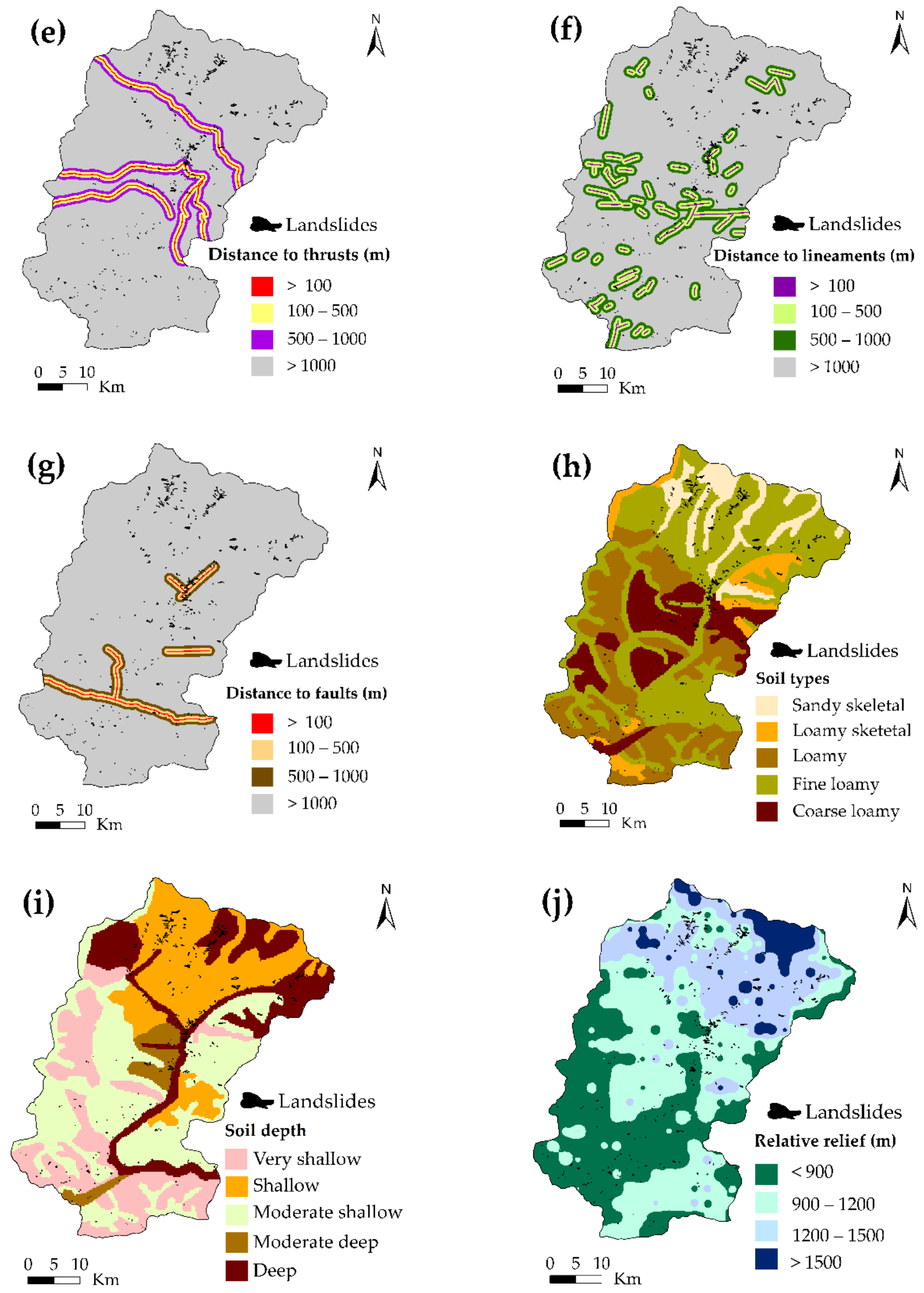

Figure 3. Cont. 

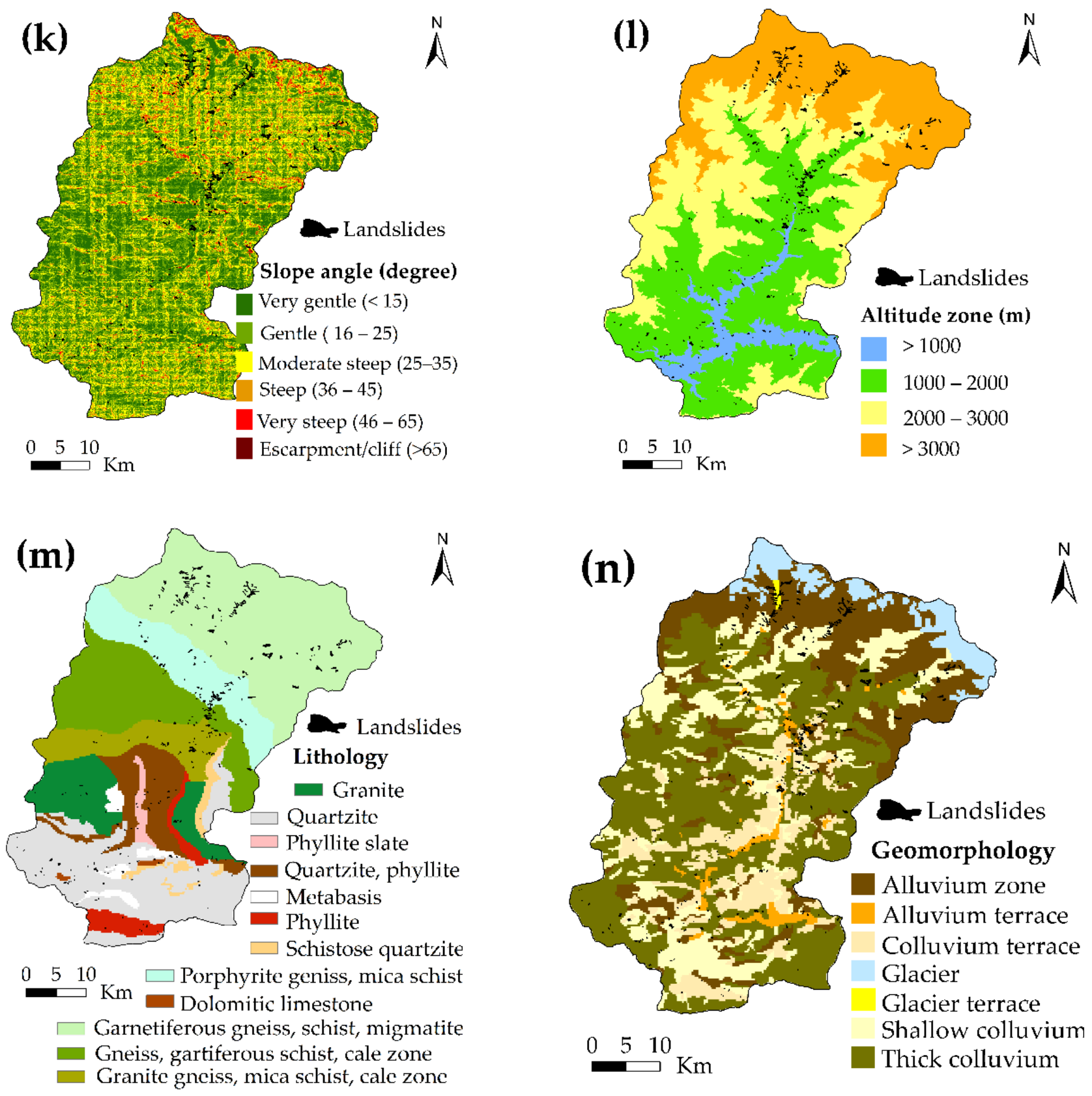

Figure 3. Landslide causative factors for the study area: (a) land-cover; (b) slope aspect; (c) distance to streams; and (d) distance to roads; (e) distance to thrust; (f) distance to lineaments; (g) distance to faults; (h) soil type; (i) slope depth; and (j) relative relief; (k) slope angle; (1) altitude zone based on rainfall; (m) lithology; and (n) geomorphology.

\subsection{Methods}

The methods for landslide susceptibility mapping are divided into two groups as: (1) weights of evidence; and (2) validation for landslide susceptibility.

\subsubsection{WoE (Weights of Evidence) Method}

In this present study, the weight of evidence (WoE) method was applied for the landslide susceptibility mapping, a data-driven method that avoids weight's subjectivity to determine the causative factors. The WoE method was originally developed to identify and explore mineral deposits $[128,129]$. The WoE method has recently been widely applied for landslide susceptibility mapping $[130,131]$. A mathematical formulation of this model is provided by [132] and described in detail by many researchers $[64,66,68,87,100,110]$. The 
WoE method is based on the assumption that the "past is the key to the future". Thus, it is believed that future landslides will occur under conditions similar to those contributing to previous landslides. We assume that the combination of causative factors is conditionally independent of one another concerning the landslides [128,131]. It is also further presumed that the combination of causative factors might have resulted in the triggering of past landslides in the present study area. Therefore, the past landslides were used in weighting the causative factors that mainly contribute to or cause landslides. The WoE method assigns a weight to each class of causative factor of a landslide based upon the presence $\left(\mathrm{W}^{+}\right)$or absence $\left(W^{-}\right)$of landslides within the area [132]. This method is a correlation between positive weight $\left(W^{+}\right)$when the event occurs and negative weight $\left(W^{-}\right)$when the event does not occur, which are defined as:

$$
\begin{aligned}
& W^{+}=\log _{e} \frac{P\{B \mid D\}}{P\{B \mid \bar{D}\}} \\
& W^{-}=\log _{e} \frac{P\{\bar{B} \mid D\}}{P\{\bar{B} \mid \bar{D}\}}
\end{aligned}
$$

where $P$ is the probability, $B$ is the presence of a desired class of landslide causative factor, $\bar{B}$ is the absence of a desired class of landslide causative factor, $D$ is the presence of landslides, and $\bar{D}$ is the absence of a landslides. Since the results are in log form. Therefore, the difference between the two weights is known as the weight contrast, $C\left(C=W^{+}-W^{-}\right)$. The magnitude of the contract reflects the overall spatial association between the causative factors and the landslides. The standardized value of $C$, calculated as the ratio of $C$ to its standard deviation, $\mathrm{S}(\mathrm{C})[64,66,68,87,110]$. The value of $W_{\text {std }}$ determines the importance of the spatial relationship between factors affecting the occurrence of a landslide. It also shows relative certainty of posterior probability [128,132].

The $S(C)$ (standard deviation) of positive and negative weights is computed as follows:

$$
S(C)=\sqrt{S^{2} W^{+}+S^{2} W^{-}}
$$

where $S^{2} W^{+}$and $S^{2} W^{-}$are the variances of $\left(W^{+}\right)$positive and $\left(W^{-}\right)$negative weights, respectively. The variances of positive and negative weights can be estimated through the following equations:

$$
\begin{aligned}
S^{2} W^{+} & =\frac{1}{N\{B \cap A\}}+\frac{1}{B \cap \bar{A}} \\
S^{2} W^{-} & =\frac{1}{\{\bar{B} \cap A\}}+\frac{1}{\bar{B} \cap \bar{A}}
\end{aligned}
$$

The standardized weight contrast $\left(W_{s t d}\right)$, i.e., the ratio of the contrast to its $S(C)$ (standard deviation), is used to calculate the confidence:

$$
W_{s t d}=(C / S(C))
$$

If the weight contrast is positive, the factor is favorable for the landslides, and if it is negative, it is unfavorable for the landslides. If the weight contrast is close to zero, the factor shows little relation to the landslides. The landslide susceptibility index (LSI) map was constructed by summing the standardized $\left(W_{s t d}\right)$ weight contrasts of each causative factor as follows: LSI $=\Sigma W_{s t d}$ (where $W_{s t d}=$ standardized weight contrast of each factor). When the LSI value is high or positive, it means that the landslide's susceptibility is high, and if the LSI value is low or negative, it means that the susceptibility of landslides is low.

\subsubsection{Validation of Landslide Susceptibility Map}

To prepare an accurate map of landslide susceptibility and find out the best suitable model, the validation of the applied method is necessary. The validation of the landslide susceptibility map was evaluated by calculating the relative operative characteristic 
(ROC) method and the percentage of the observed landslide in various susceptibility categories $[133,134]$. The area under the curve (AUC) of the ROC represents the quality of the probabilistic model (its ability to predict the occurrence or non-occurrence of an event) [135]. An AUC value close to 1 indicates high accuracy, and an AUC value close to 0.5 indicates inaccuracy $[135,136]$. In this study, the success-rate curves were obtained using the IDRISI SELVA17.0 software package. The AUC values obtained from the susceptibility maps and testing landslides show that the model gave the highest success rate.

\section{Results}

\subsection{Landslide Inventory Map}

In order to apply the WoE method, 293 landslide polygons were identified from 2011 to 2013, which were based upon BHUVAN and high-resolution Google Earth ${ }^{\circledR}$ imagery. Landslides cover an area of about $7.46 \mathrm{~km}^{2}$ (total of 74,704 grid cells), which is $0.38 \%$ of the total study area. The final output of the multi-temporal landslide inventory map of the district is shown in Figure 4.
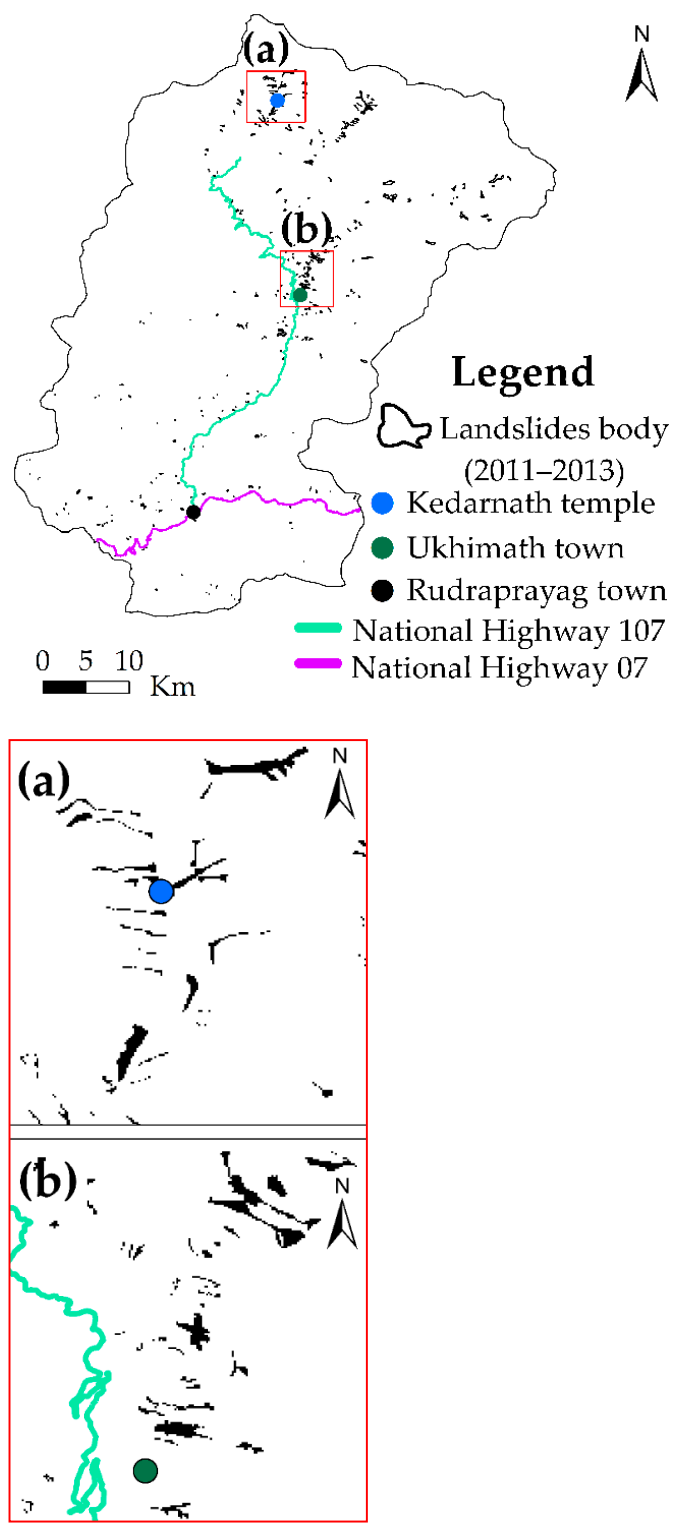

Figure 4. The distribution map of landslide body in the Rudraprayag district (2011-2013). 


\subsection{Landslide Susceptibility Map}

The landslide susceptibility map was obtained using the WoE method. Figure 5a shows the overall standardized weight contrast value, i.e., positive weight contrast and negative weight contrast. Figure $5 \mathrm{~b}$ shows the final landslide susceptibility maps of the Rudraprayag district. The landslide susceptibility was divided into five classes by the natural break method using ArcGIS. Figure $5 \mathrm{~b}$ shows that $14.43 \%$ of the area falls under the very high susceptibility class, $18.69 \%$ of the area falls under the high susceptibility class, while $19.45 \%, 27.42 \%$, and $20.01 \%$ of the area belong to medium, low, and very low susceptibility classes, respectively.
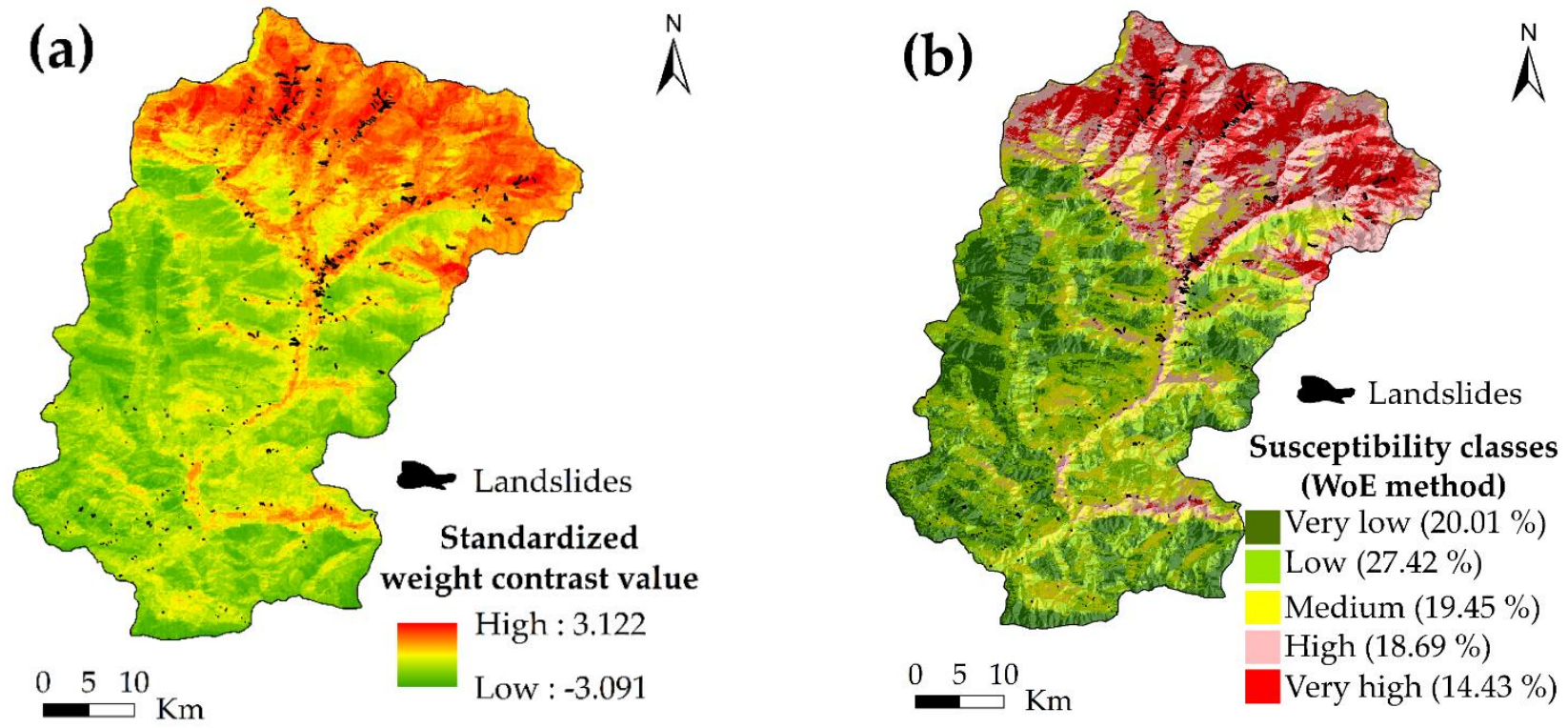

Figure 5. (a) Landslide susceptibility map showing the range of all standardized weight contract values, i.e., negative and positive; (b) the distribution of the landslide susceptibility classes.

\subsection{Validation of Landslide Susceptibility Map}

The validation of the landslide susceptibility map was checked against randomly selected landslides. The ROC (AUC) curve of model performance is shown in Figure 6. The AUC value indicates that the WoE method gave a high success rate $(A U C=0.857)$. The resulting map of areas susceptible to landslides has a prediction accuracy of $85.7 \%$.

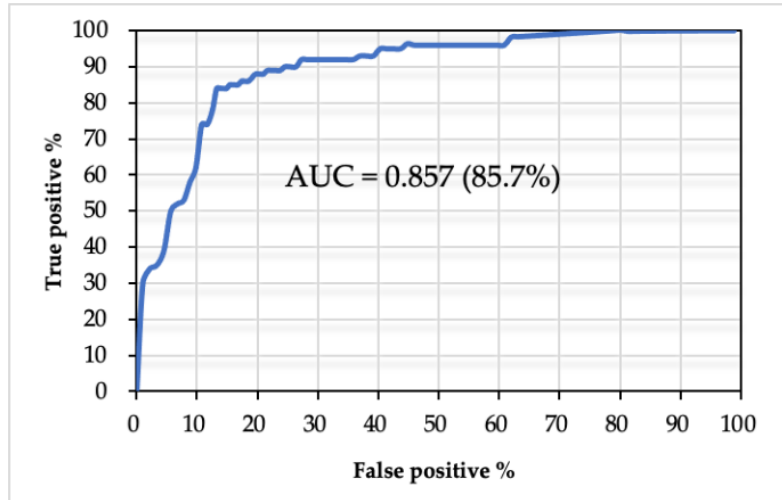

Figure 6. The graph showing validation of landslide susceptibility map under the ROC (AUC) curve using the IDRISI Selva 17.0 software. 


\subsection{Analysis of Landslide Susceptibility Map}

Figure 7 shows the graphs of landslide susceptibility causative factors and their corresponding standardized weight contract value: positive weight contrast and negative weight contrast. Regarding the land use/cover factor, the landslide susceptibility is high in non-forest areas such as scrubland, pastureland, barren land, built-up area, and agricultural land. This shows that there is a strong correlation between the non-forest area and the landslide occurrence (Figure 7a). In the case of slope aspect factor, the most susceptible classes were southeast, south, and west-facing slopes (Figure $7 \mathrm{~b}$ ). In the case of distance to streams and roads, the susceptibility of the landslide was reduced (i.e., $>1000 \mathrm{~m}$ ) with increasing distance. Therefore, the standardized weigh contract indicates a strong correlation between landslide occurrences and distance from streams (Figure 7c) and roads (Figure $7 \mathrm{~d}$ ). The standardized weight contract value indicates a strong correlation between landslide occurrences and geological structures like Main Central Thrusts (MCT) and faults (Figure 7e,g). A low correlation was observed near to lineaments (Figure 7f). In this study, the most susceptible soil types are fine loamy and loamy skeletal (Figure 7h). In the case of soil depth, the majority of landslides were observed in shallow and deep soil classes (Figure 7i). The frequency of landslide was observed on the steep slopes (Figure 3k) in the upper catchment of the Mandakini river (Figure 3j), where relative relief was high (1200-1500 m). This indicates that the high relative relief influences the frequency of landslides (Figure 7j). The standardized weight contrast values of the slope were high in steep slopes, except slope above 65 degrees (Figure 7j). The rainfall is highly variable depending upon the altitude in this study area. The altitude zone higher than $3000 \mathrm{~m}$ is the most susceptible to landslide occurrence (Figure 7l). This landslide occurrence may be due to lack of vegetation at high altitudes $(>300 \mathrm{~m})$, which can further enhance landslides occurrence during heavy rainfall. In the order of importance, the most susceptible classes of the lithology factor are (1) garnetiferous gneiss, schist, and migmatite, (2) porphyritic gneiss and mica schist, and (3) granite gneiss, mica schist, cale zones (Figure $7 \mathrm{~m}$ ). Regarding the geomorphology factor, the most susceptible classes are the alluvium zone, alluvium terrace, and glacier terrace (Figure $7 \mathrm{n}$ ). In conclusion, the study results show that medium to very high landslide susceptibilities had occurred in the non-forest areas, mainly scrubland, pastureland, and barren land. The results also show that landslide susceptibility is high in high altitude zone, thrusts, faults, shallow soil, and southeast, south, and west-facing steep slopes.

(a)

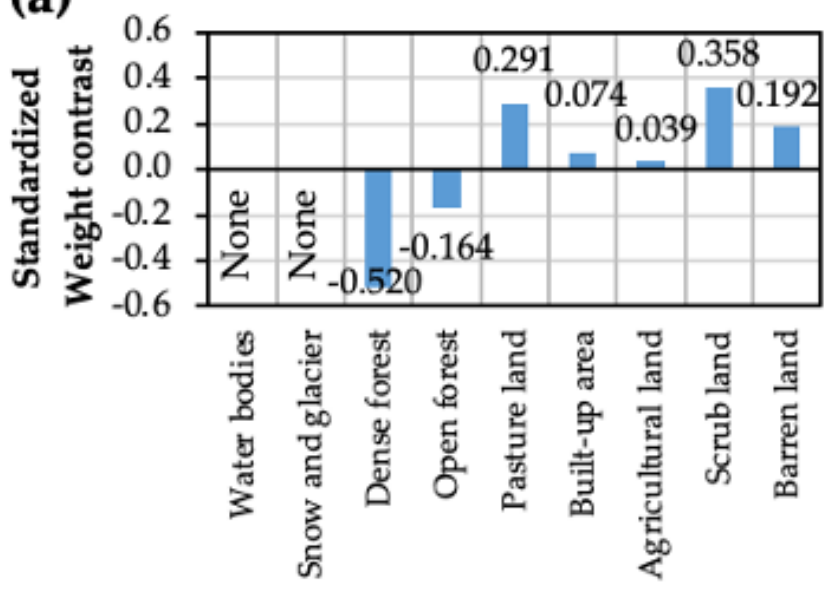

(b)

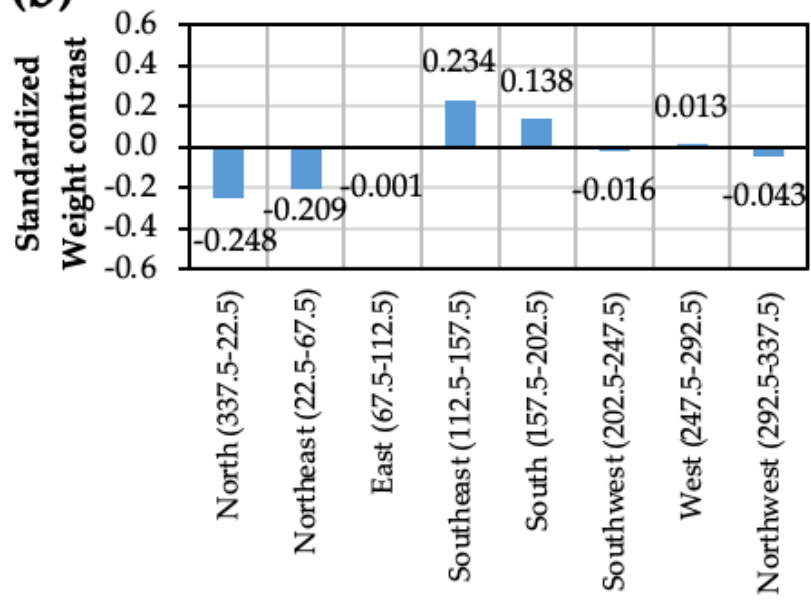

Figure 7. Cont. 
(c)

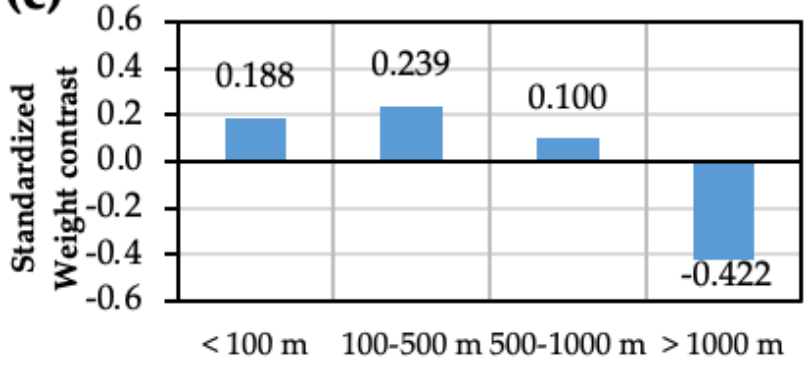

(e)

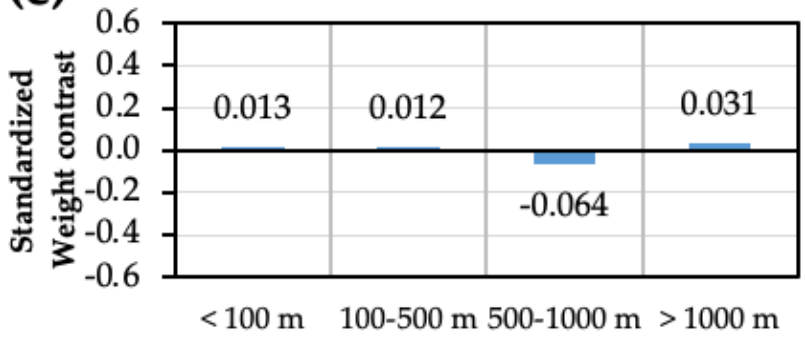

(g)

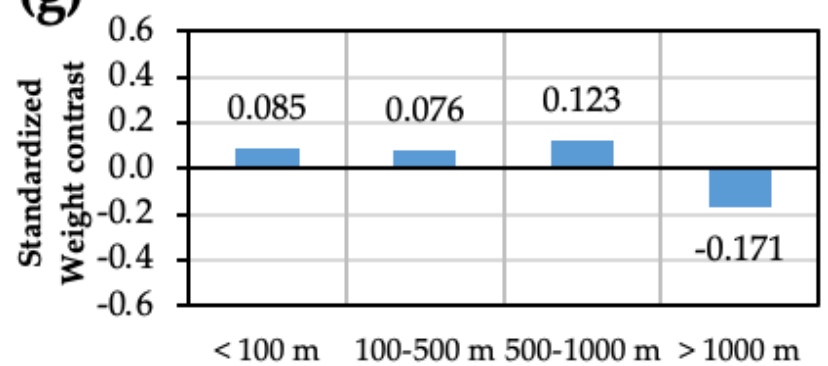

(i)

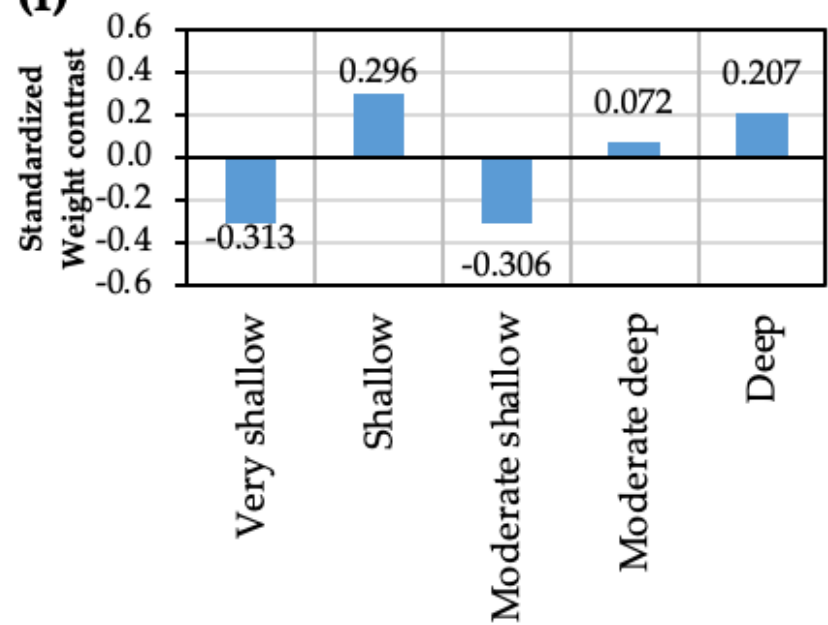

(d)

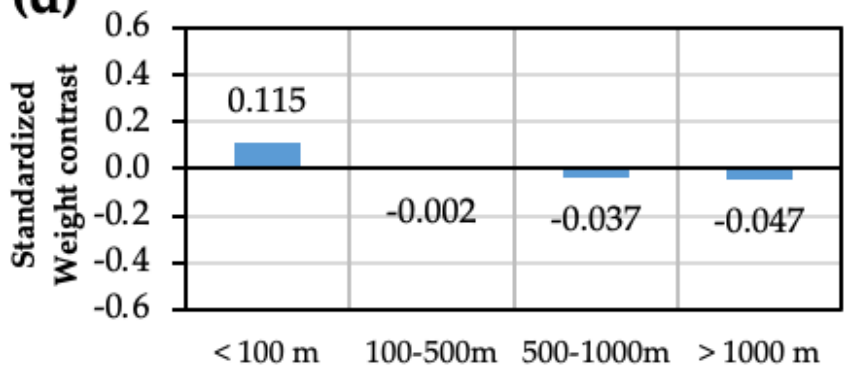

(f)

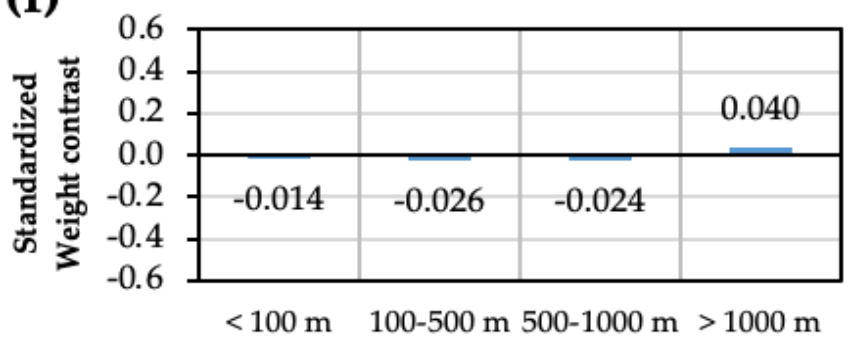

(h)

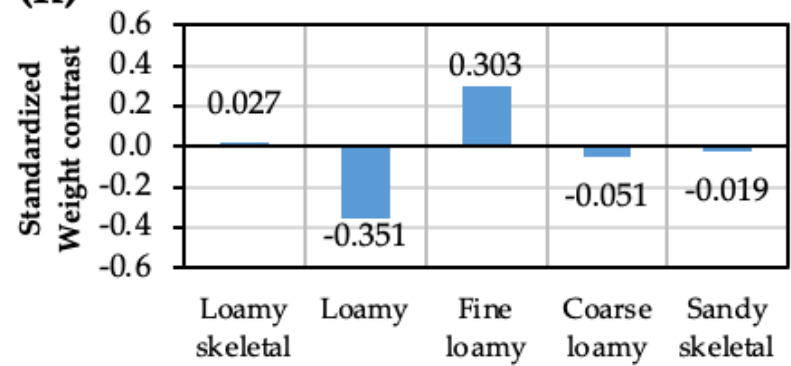

(j)

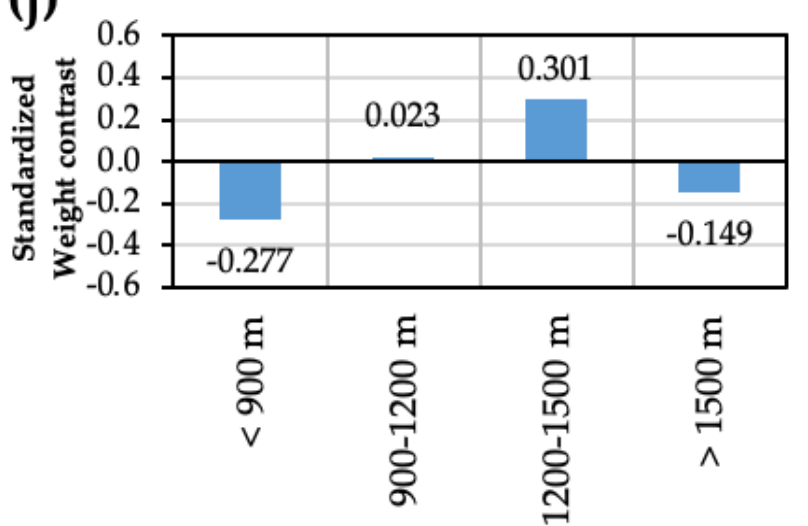

Figure 7. Cont. 
(k)
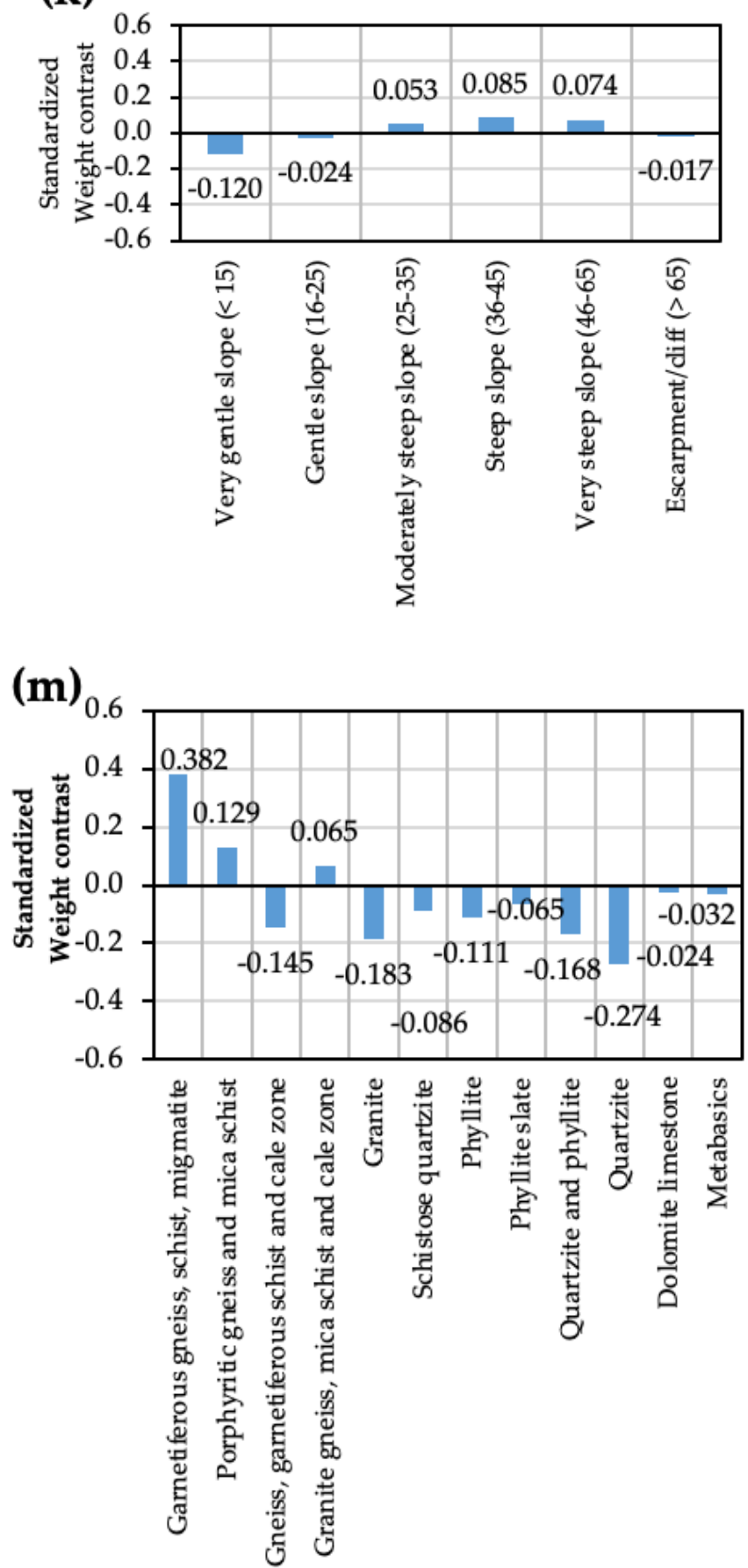

(1)

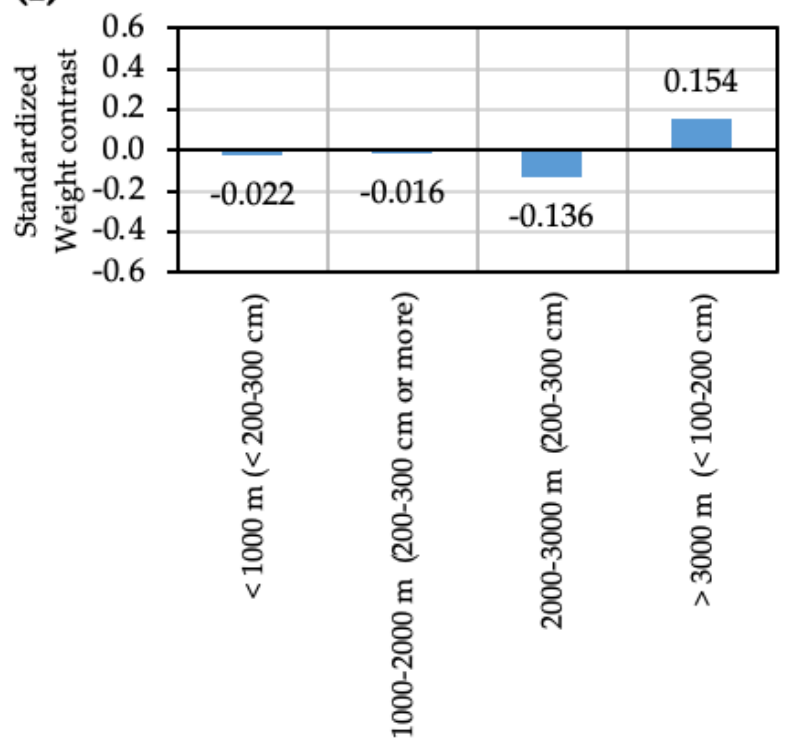

(n)

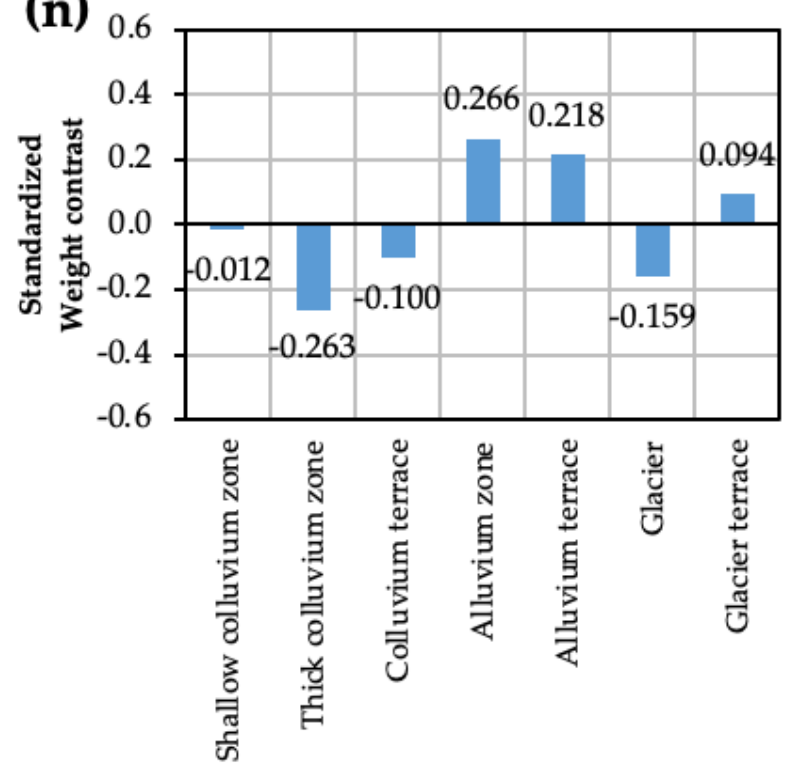

Figure 7. The graphs of landslide causative factors and their corresponding standardized weight contract value: (a) land use/cover; (b) slope aspect; (c) distance to streams; (d) distance to roads; (e) distance to thrust; and (f) distance to lineaments; (g) distance to faults; (h) soil type; (i) slope depth; (j) relative relief; (k) slope angle; and (1) altitude zone based on rainfall; (m) lithology; and (n) geomorphology.

\section{Discussion}

\subsection{Landslide Susceptibility Mapping (Present Study)}

A quantitative approach was applied to prepare the landslide susceptibility map in the GIS environment at the district level. Due to the data-scarce environment, the combined use of the BHUVAN and Google Earth ${ }^{\circledR}$ web-based platforms provided a useful tool to prepare spatio-temporal landslides inventory of the study area. The landslide susceptibility or 
hazard mapping and risk assessment are always hampered due to lack of multi-temporal landslide inventory, expensive high-resolution satellite images, and limited landslide historical records in India $[14,96]$. In addition, the low-optical remote sensing satellite images may not be sufficient to identify the landslides in forested land due to shadow and cloud cover issues in the Indian Himalayas [14]. Therefore, high-resolution satellite data are needed for better hazard mapping and assessment. The previous studies used point data of landslides to prepare the landslide susceptibility mapping [119]. However, the point data of landslide occurrences do not consider the magnitude and volume of landslides and can yield biased results regarding the degree of landslide susceptibility or hazard zonation [65]. Therefore, the development of landslide polygon data is more helpful to prepare effective landslide susceptibility or hazard map and for further assessment related to landslide hazards.

In this study, fourteen factors causing landslides were selected based on data availability and previous studies conducted in the Rudraprayag district $[95,126,127]$. The WoE method was applied to assign the weights to each class of all causative factors to obtain a landslide susceptibility map. Later, the validation of the landslide susceptibility map was checked against randomly selected landslides [127]. The WoE method achieved a prediction accuracy of $85.7 \%$, which indicates that the model gave good accuracy $[65,68,100,110]$. However, the previous studies suggested that the collinearity between causative factors and landslide occurrence can affect the model performance. Therefore, the multicollinearity analysis of causative factors should be performed for achieving better accuracy of the model $[80,87,100]$. It is clear now that model performance depends on identifying the significant factors related to landslides occurrences, quality of the spatial and attribute data, landslides inventory data, scale and size of the study area, and uncertainties associated with digitizing the data. The WoE method with accuracy assessment has been applied before by [95] at the small watershed in the Rudraprayag district. However, the WoE method has not been attempted at the district level. The previous studies conducted in India suggested that the BIS method has some degree of uncertainty because of the fixed ranking of geo-factors [93-95]. In addition, the APH method has uncertainty regarding the selection of ranking of geo-factors, as discuss in detail in Section 4.2.1. Therefore, the WoE method was applied to avoid the subjectivity existing in the BIS and APH methods.

The results clearly showed that medium to high landslide susceptibilities had occurred in the non-forest areas, mainly scrubland, pastureland, and barren land. Our result indicated that the landslide susceptibility is highest in the scrubland than other land covers (Figure 7a). The Forest Survey of India (FSI) and previous studies indicated that the scrubland is degraded forest-cover [14]. Therefore, there is a possibility of an increase in landslide occurrences in scrubland in the near future. The majority of the agricultural lands and built-up areas are near the major roads and river channels in the study area [14]. Our results showed that medium to very high landslide susceptibilities areas have occurred near the major roads (National Highway 107 and 07) and the Mandakini river channels, indicating high risk in agricultural land and built-up area (Figure 1). According to the previous study, the study area covers $68 \%$ of forest areas and $32 \%$ non-forest areas, and the majority of the non-forest areas are at higher altitudes and steep slopes [14]. The results showed that landslide susceptibility is high in non-forest areas. Due to this, the landslide susceptibility is high at higher altitudes (>3000 $\mathrm{m}$ ) and steep slopes (36-45 degrees). Therefore, the landslide hazard risk is high on the upper catchment of the Mandakini river and the steep slopes.

In this study area, the upper catchment areas of the Mandakini river are a protected area as a wildlife sanctuary and famous tourist hotpot (Kedarnath and Tungnath temple) [14]. The relative relief can increase the size, magnitude of the landslide, which can affect the overall landscape [117]. The result showed that landslide susceptibility is high in higher relative relief at the upper catchment area of the Mandakini river. This indicates the high risk on human activities and wildlife sanctuary due to landslide hazards, which cannot be ignored. An increase in soil moisture and lack of vegetation can lead to landslide 
occurrences and further enhance the rainfall-induced shallow landslide. In this study, most of the landslide occurrences were associated with lack of vegetation in fine loamy and sandy skeletal areas at the upper catchment and along the Mandakini river (Figure 3a,h). In addition, most of the landslide occurrences were observed in shallow and deep soil depth (Figures $3 \mathrm{i}$ and 7i). Generally, the slope aspect was ignored for landslide susceptibility or hazard zonation mapping in the previous studies [119]. However, the slope aspect may influence the weathering processes due to the possibility of sunlight, which might play a significant role in the breakdown of rock. In this study, the southeast, south, and west-facing slopes have the highest landslide susceptibilities, indicating the risk on the agricultural land and built-up areas facing this direction [117]. The Rudraprayag district is under the high-risk earthquake zone because the Main Central Thrust (MCT) is passing through this area [121]. Therefore, the results clearly indicated that landslide risk is high near the Main Central Thrust (MCT) in this study area. However, the landslide mechanisms in the Indian Himalayan Region are very complicated and mainly controlled by geologic conditions [122] and also triggered by external factors [118]. Under the climatic conditions, the rainfall intensity is likely to be more susceptible to landslide occurrences in this study area [117], as summarized previously in Section 2.1. Therefore, human activities, material damage, and life are at high risk due to landslides triggered by rainfall. That is why the additional and detailed geologic information, high-resolution datasets, and external factors related to spatial data such as rainfall intensity/duration and earthquake intensity should be used for landslide susceptibility mapping and assessment in the future. There were no landslides observed in snow/glacier areas and near to lineament $(>1000 \mathrm{~m})$. Moreover, we could not evaluate the role of temperature, groundwater, and snowmelt influence on the landslides hazard even though their potential influence may be significant. We think that the result is satisfactory for a study at a regional scale $\left(1936.06 \mathrm{~km}^{2}\right)$ study.

The development of multi-temporal landslide inventory dating is needed to prepare the more effective landslide susceptibility mapping and understand the short and long-term effects of landslide occurrences on the natural environment $[14,18,19,136]$. The rainfall, flash flood, cloudbursts triggered landslide occurrences are common in this study area [112-120]. Therefore, we prepared landslide inventory triggered by multiple events such as heavy rainfall, cloudburst, and flash flood from 2011 to 2013, as reported in the government reports, BHUVAN, and previous studies [99,106,112-120]. This landslide susceptibility map might be helpful compared to the single event-based landslide susceptibility mapping prepared by other researchers for this landslide-prone area $[97,99,109]$. In addition, the landslide susceptibility map prepared by other researchers $[119,120]$ showed that the higher altitude and lower to middle catchment areas of the Mandakini river had less susceptibility (low landslide hazard zone) to the landslide. However, our landslide susceptibility map showed high landslide susceptibility in these areas, since many landslides were observed in these areas from 2011 to 2013 . Moreover, the Himalayan region and hilly areas in India are facing different types of landslide occurrences due to both internal and external factors [117]. The fragile nature of the Indian Himalayas, changes in climatic patterns, and continuous human disturbance in land cover by development activities can lead to more landslides in this landslide-prone area, which cannot be ignored [14]. The study area gained importance due to the pilgrimage site (Kedarnath temple) and protected land as a Kedarnath wildlife sanctuary in the upper catchment of the Mandakini river. Thus, this landslide susceptibility map could help the local governments in landslide hazard mitigation, land use planning, and landscape protection.

\subsection{Landslide Susceptibility, Hazard Mapping, and Risk Assessment in India: Recent Developments, Gaps, and Future Directions}

The Himalayan Region and hilly areas in India are highly prone to natural disasters, including landslides. The landslide susceptibility mapping and assessment are necessary for the comprehensive understanding of the spatial and temporal occurrence of landslides, which is a vital tool to identify the hazardous areas and to mitigate the landslide hazard risk. However, the landslide related database and research are still inadequate in these 
landslide-prone areas. At first, we address the current progress and gaps related to landslide inventory, susceptibility, and risk assessment in the Indian context in Section 4.2.1. After that, we discuss some opportunities for improvement related to landslide inventory, susceptibility, and risk assessment in the Indian context in Section 4.2.2.

4.2.1. Landslide Susceptibility, Hazard Mapping, and Risk Assessment in India: Recent Developments and Gaps

Since Disaster Risk Reduction (DRR) is a holistic approach, identifying hazard areas is an essential component of disaster management and an essential basis for understanding disaster risk. By this, the magnitude of disaster can be minimized, and the economic loss may be lessened. In this regard, the national-level institutions and organizations that are accountable for mapping, assessment, and risk analysis for natural hazards in India include the National Remote Sensing Centre (NRSC), Indian Institute of Remote Sensing (IIRS) under the Indian Space Research Organization (ISRO), Geological Survey of India (GSI) under the Ministry of Mine, National Institute of Disaster Management (NIDM) under the Ministry of Home Affairs, Building Materials and Technology Promotion Council (BMTPC) under the Ministry of Housing and Urban Affairs, and National Atlas and Thematic Mapping Organization (NATMO) under the Ministry of Science and Technology, Government of India. We discuss their recent development, gaps related to landslides inventory, susceptibility mapping, and risk assessment in the following paragraphs.

The GSI contributes a significant role to geology and geomorphology related research in India and has been designated as the nodal agency for natural hazards, including landslide hazards. Thus, the GSI is accountable for landslide inventory, susceptibility, and hazard assessment. Recently, the GSI has launched a national program called national landslide susceptibility mapping (NLSM). This program aims to create a dynamic national landslide susceptibility geodatabase for India, prepare GIS-based seamless landslide susceptibility maps of India on a 1:50,000 scale, and prepare a nation-wide repository on GIS-based landslide inventory. The GSI also provides an online gateway called BHUKOSH (https:/ /bhukosh.gsi.gov.in/ (accessed on 17 November 2020)) to all geoscientific related geology and geomorphology data, where landslide inventory, susceptibility mapping, and landslide-related geo-factors can visualize, download, and digitized using an online tool. The methodology applied by GSI to obtain landslide susceptibility maps is based on spatial association analysis between fixed geo-factors and landslides (point data of landslide occurrences) using the analytical hierarchy process (APH) to determine the rating of factors of each class and weights of geo-factors along with knowledge-driven estimation. The APH method is a semi-quantitative decision using weights through the pair-wise relative comparison without inconsistencies in the decision process. However, the APH method is uncertain regarding the selection of ranking of geo-factors, as it may differ from one expert to another. Therefore, other quantitative approaches and machine learning (ML) techniques can be applied to compare or combine with APH to prepare the useful landslide susceptibility mapping. Moreover, the landslide point data ignore the volume and magnitude and might yield a biased result regarding the degree of landslide susceptibility. Therefore, the GSI can prepare the multiple-temporal landslide (landslide as a polygon) inventory to prepare the practical landslide susceptibility map and further assess the landslide impact on the natural environment.

The NRSC, Department of Space (DOS) of the Indian Space Research Organization (ISRO), Government of India has established a disaster management support program (DMSP) and services including landslide hazard mapping, landslide inventory, and landslide early warning system for disaster monitoring, mitigation, relief, and management at lo$\mathrm{cal} / \mathrm{state} /$ national level. The geospatial data can be visualized, digitized, and download via web-based geo-portal like BHUVAN (https:/ / bhuvan.nrsc.gov.in (accessed on 17 November 2020)), BHOONIDHI (https:/ / bhoonidhi.nrsc.gov.in (accessed on 17 November 2020)), and National Database for Emergency Management (NDEM) (https:/ /ndem.nrsc.gov.in (accessed on 17 November 2020)). The NRSC plays a significant role in using the earth observation data for landslide inventory and landslide hazards zones mapping. The NRSC 
has developed a semi-automatic image analysis algorithm approach for the preparation of new and historical landslide inventories [95]. The NRSC also applied APH methods to produce the landslide hazard zones. The landslide inventories (from 2011) are limited and event-based (e.g., events like rainfall, cloudburst, and earthquakes). However, the landslide types and non-event-based landslide inventories are still limited. The landslide susceptibility or hazard zone mapping is also limited and based on triggering factors, mainly rainfall and earthquake events, and limited to the major tourist and pilgrimage routes of two states, namely Himachal and Uttarakhand in the Indian Himalayan region. Therefore, multi spatial-temporal and non-event landslide inventory database are required to prepare a significant landslide susceptibility or hazard mapping and risk assessment.

To achieve a global agreement of disaster risk reduction set by the Hyogo framework (2005-2015) and Sendai framework (2015-2030), the BMTPC plays a significant role in promoting disaster mitigation measures through preparedness. The BMTPC published the 3rd edition of the vulnerability atlas of India in March 2019. The vulnerability atlas includes different existing hazard scenarios for the entire country and presents hazard maps in the digitized form at state/union territory-level separately. The vulnerability atlas also presents district-wise identification of vulnerable areas concerning earthquakes, winds, floods, thunderstorms, cyclones, and landslides. The database to prepare the vulnerability atlas of India was acquired from existing data from government nodal agencies of India, such as the Indian Survey of India (SOI), Geological Survey of India (GSI), Census of India, Central Water Commission (CWC), Meteorological Department (IMD), and Bureau of Indian Standards (BIS). The natural hazards maps given in this vulnerability atlas, including landslide hazard zonation and landslide incidence map (https://bmtpc.org/ (accessed on 17 November 2020)), were prepared up to the district level, and given maps are available in the digital form and hard copy. The thematic map needs permission for commercial use by BMTPC. The atlas also presents district-wise housing vulnerability risk in tabular form based on wall and roof types as per 2011 Indian census housing data.

However, the available historic landslide data presented in this vulnerability atlas have been mapped through field validation till 2016 by geoscientists. The point location (9883) of landslides was mapped based on field-based eyes-estimation only at the accessible locations. Therefore, there is a possibility that many more landslides might occur in remote and inaccessible locations. Therefore, provided landslide inventory data might yield biased results for the risk assessment without proper landslide distribution data. The vulnerability atlas provided details of the house types, risk of damage to house types, damage risk levels in tables form caused by earthquakes, windstorms, and floods. However, the riskrelated table provided by BMPTC can be more user-friendly if the provided table can enter into the GIS software for further assessment. Moreover, the 3rd addition of the vulnerability atlas mainly focuses on vulnerability and risk to human activities, and less consideration was made to the natural environment. It should be noted that the frequency and magnitude of landslides can affect the natural landscape, which cannot be ignored in rich biodiversity regions like Indian Himalayas. Therefore, a holistic approach is needed to address multiple hazards and risk analysis for promoting safe human occupations, infrastructure development, and landscape protection in landslide-prone areas.

The NATMO under the Department of Science and Technology, Government of India, is assigned with responsibility regarding the atlas services of different thematic cartography, including natural hazards such as landslides, earthquakes at local, regional, national levels. The features of thematic data can be drawn and visualized by geoportal (http: //geoportal.natmo.gov.in/ (accessed on 17 November 2020)). However, the thematic data related to natural hazards are too general on the given map, and all-natural hazard themes are provided in a single map, which is also not up to date. In addition, the data sources to prepare natural hazards maps are not mentioned by NATMO. Therefore, further detailed information on input data and analysis methods is needed.

Since the Disaster Management Act of 2005, the NIDM contributes a significant role in disaster management and disaster risk reduction at the local/regional/national 
level. It is assigned as a nodal agency in policy advocacy, capacity building, human resource development, training, research, and guideline and documentation related to disaster management. The NIDM supports various national and state-level agencies and plays a vital role in disaster prevention and preparedness. The NIDM published many significant case studies/research, including disaster and annual reports every year, which are very useful and available freely (https://nidm.gov.in/ (accessed on 17 November 2020)). However, the case study/research done by NIDM is goal-oriented and mainly focused on event-based hazards (e.g., earthquake, flood, cyclone, and heatwave) in specific areas. Since the number of tourists is increasing at many religious and tourist sites in the Indian Himalayas, the government must enhance landslide early warning systems and devices on a large scale beyond the pilgrim sites to keep its citizens informed and mitigate damage from landslide hazards.

\subsubsection{Landslide Susceptibility, Hazard Mapping, and Risk Assessment in India: Future} Directions

Based on the above-mentioned landslide hazards related to recent developments and gaps in the Indian context, we discuss some opportunities for improvement related to landslide inventory, susceptibility, hazard mapping, and risk assessment in the Indian context, which are the following:

To improve landslide susceptibility or hazard mapping and risk assessment, the multi-temporal landslide inventory and their accurate spatial distribution is necessary for effective hazards mapping. The uses of low-resolution optical satellite images might be challenging for the detection of landslide and types due to shadow and cloud cover problems in the high mountainous terrains like the Himalayas. In addition, the low-resolution optical satellite image can lead to misclassification for the landslide identification, which can yield biased results for landslide susceptibility or hazard mapping and risk assessment. Therefore, the government organizations/institutions may use high-resolution Light Detection and Ranging (LiDAR) and Radio Detection and Ranging (RADAR) remote sensing data to prepare the multi-temporal landslides inventory that occurred in non-forest and forested land. Despite the fact that the long-term landslide inventory and types of landslide data are still lacking in India, today there are useful machine learning techniques and web-based geospatial platforms available to identify landslides, which can significantly help to prepare the multi-temporal landslide inventory in high mountainous terrain due to often limited access areas and in the data-scarce environment. Thus, landslide inventory data can be derived through newly available machine learning techniques and web-based geospatial platforms such as Google Earth ${ }^{\circledR}$, BHUVAN, etc., where a low-resolution satellite image might not be helpful due to cloud cover and shadow problems in high mountainous terrain. Moreover, multi-temporal landslide inventory and type of landslide are important to understand the short and long-term effects on natural environment by landslide occurrence.

The efforts made towards landslide inventory, susceptibility, or hazard zonation and risk assessment by government institutions/organizations are considerable. However, the susceptibility or hazard mapping and risk assessment related methods, techniques, scale, area of interest are varied from one another. In addition, the various input datasets related to available methods are still limited, challenging, and restricted to acquire to some extent. Taking into account the needs of different categories of users, the government needs to develop more user-friendly landslide database and platform like BHUVAN. Moreover, it should be noted that above all, mentioned organizations/institutions focus on different types of hazards and their methodology approaches separately to tackle the disaster risk in the Himalaya region and hilly areas in India. However, one hazard influences other hazards. As a result, multiple hazards are affecting the same natural landscape with serious environmental problems in the Himalayan region and hilly areas in India. Therefore, a holistic approach through multiple hazards mapping and risk assessment could help for disaster risk reduction in a more effective way. Although very few suggestions were made so far by researchers. 
The development of an administrative level or small-scale mapping of landslide susceptibility, hazard zonation, and risk assessment is required to implement risk management plans and effectively mitigate landslide hazards risk. However, most of the landslide susceptibility, hazard zonation map is lacking at the administrative level such as district, tehsil, block, and village level. Therefore, the researchers and government organizations/institutions need an integrated interdisciplinary approach for disaster risk reductions to understand the short and long-term effects of landslide occurrences and to promote safe human activities, infrastructure development, and protect the natural environment in landslide prone areas at different level.

Identifying hazard areas and risk assessment is vital to disaster risk reduction. A useful tool/technique for monitoring landslide occurrences, mapping landslide susceptibility, or hazards and risk assessment could help local governments to mitigate the associated economic losses and protect the natural landscape. Therefore, it is critically important to compare and determine the appropriate model for landslide inventory, susceptibility, or hazard zonation mapping at the local/regional/national level.

Moreover, India is also committed to making all efforts by improving the entire disaster management cycle to contribute to the global agreement towards disaster risk reduction by following the Sendai Framework's recommendations. In this regard, the National Disaster Management Authority (NDMA) is the highest level of a government body for disaster management in India. The NDMA plays a significant role by implementing disaster risk mitigation and management-related policies, plans, and guidelines. There is no doubt that significant progress has been made or under progress towards disaster risk reduction, including landslide by the NDMA. However, many actions still need to consider and their implementation on global, national, regional, and local levels based on four priorities according to Sendai Framework (2015-2030).

\section{Conclusions}

The Himalayan region and hilly areas in India face severe challenges due to landslide occurrences. Therefore, landslide susceptibility mapping is a vital tool to identify hazardous areas and an essential basis for promoting safe human occupations, infrastructure development, and landscape protection in this landslide-prone area. This study demonstrated the significant combined use of BHUVAN and Google Earth ${ }^{\circledR}$ to prepare multi-temporal landslides inventory (polygon data) to access landslide susceptibility map in the data-scarce environment in the Rudraprayag district. Fourteen landslide causative factors were considered based upon previous studies and ancillary information, fieldwork. Then, we applied quantitative approach (bivariate statistical method), i.e., the WoE method to avoid weight's subjectivity to determine the causative factors that exist in the BIS and APH methods. The WoE method achieved a prediction accuracy of $85.7 \%$, indicating good accuracy of the model. The study area gained importance due to the pilgrimage site (Kedarnath temple) and wildlife sanctuary. Therefore, this landslide susceptibility map of the Rudraprayag district could help the local authorities in land use planning, landscape protection, and mitigate the risk from landslide hazards. The landslide related database and research are still inadequate in rich biodiversity region like the Himalayas. This hampers the further analysis of landslide hazard related assessment due to the lack of multi-temporal landslide inventory, expensive high-resolution satellite images, and limited landslide historical records in the Indian Himalayan region. Therefore, we provided a comprehensive review of recent developments, gaps, and future directions related to landslide inventory, susceptibility mapping, and risk assessment in the Indian context. Thus, this present research fulfills the research gaps taking the example of the Rudraprayag district, a landslide-prone area in the Indian Himalayan Region.

Author Contributions: Conceptualization, methodology, software, formal analysis, writing-original draft preparation, Amit Kumar Batar; writing-review and editing, Amit Kumar Batar and Teiji Watanabe. Both authors have read and agreed to the published version of the manuscript. 
Funding: This research received no external funding.

Acknowledgments: We want to acknowledge free access of geospatial data on the BHUVAN platform provided by the Indian Space Research Organization (ISRO). We want to thank Arun Mishra, Ajay Kumar Gurjar, Rajkamal Kumar, Nirmit Sakre, Eshank Batar, and the local people of Rudraprayag district for their help during the fieldwork. This study contributes to the Global Land Programme (GLP), a global research project of Future Earth.

Conflicts of Interest: The authors declare no conflict of interest. The founding sponsors had no role in the design of the study; in the collection, analyses, or interpretation of data; in the writing of the manuscript, and in the decision to publish the results.

\section{References}

1. Keefer, D.K. Landslides caused by earthquakes. Geol. Soc. Am. Bull. 1984, 95, 406-421. [CrossRef]

2. Hansen, A. Landslide hazard analysis. In Slope Instability; Brunsden, D., Prior, E., Eds.; Wiley: New York, NY, USA, 1984; pp. 523-602.

3. Dai, F.C.; Lee, C.F.; Ngai, Y.Y. Landslide risk assessment and management: An overview. Eng. Geol. 2002, 64, 65-87. [CrossRef]

4. Dahal, R.K.; Hasegawa, S.; Masuda, T.; Yamanaka, M. Roadside slope failures in Nepal during torrential rainfall and their mitigation. Disaster Mitig. Debris Flowsslope Fail. Landslides 2006, 2, 503-514.

5. Glade, T. Landslide occurrence as a response to land use change: A review of evidence from New Zealand. Catena 2003, 51, 297-314. [CrossRef]

6. Tropeano, D.; Turconi, L. Using historical documents for landslide, debris flow and stream flood prevention. Applications in northern Italy. Nat. Hazards 2004, 31, 663-679. [CrossRef]

7. Van Beek, L.P.H.; Van Asch, T.W.J. Regional assessment of the effects of land-use change on landslide hazard by means of physically based modelling. Nat. Hazards 2004, 31, 289-304. [CrossRef]

8. Gorsevski, P.V.; Gessler, P.E.; Foltz, R.B.; Elliot, W.J. Spatial Prediction of Landslide Hazard Using Logistic Regression and ROC Analysis. Trans. GIS 2006, 10, 395-415. [CrossRef]

9. Raghuvanshi, T.K.; Ibrahim, J.; Ayalew, D. Slope stability susceptibility evaluation parameter (SSEP) rating scheme-An approach for landslide hazard zonation. J. Afr. Earth Sci. 2014, 99, 595-612. [CrossRef]

10. Schuster, R.L.; Fleming, R.W. Economic losses and fatalities due to landslides. Bull. Am. Assoc. Eng. Geosci. 1986, 23, 11-28. [CrossRef]

11. Kanungo, D.P.; Arora, M.K.; Sarkar, S.; Gupta, R.P. A comparative study of conventional, ANN black box, fuzzy and combined neural and fuzzy weighting procedures for landslide susceptibility zonation in Darjeeling Himalayas. Eng. Geol. 2006, 85, 347-366. [CrossRef]

12. Fell, R.; Corominas, J.; Bonnard, C.; Cascini, L.; Leroi, E.; Savage, W.Z. Guidelines for landslide susceptibility, hazard and risk zoning for land use planning. Eng. Geol. 2008, 102, 85-98. [CrossRef]

13. Promper, C.; Puissant, A.; Malet, J.P.; Glade, T. Analysis of land cover changes in the past and the future as contribution to landslide risk scenarios. Appl. Geogr. 2014, 53, 11-19. [CrossRef]

14. Batar, A.K.; Watanabe, T.; Kumar, A. Assessment of Land-Use/Land-Cover Change and Forest Fragmentation in the Garhwal Himalayan Region of India. Environments 2017, 4, 34. [CrossRef]

15. Greenway, D.R. Vegetation and slope stability. In Slope Stability; Gerson, M., Richards, K.S., Eds.; John Wiley and Sons: Chichester UK, 1987; pp. 187-230.

16. Meusburger, K.; Alewell, C. Impacts of anthropogenic and environmental factors on the occurrence of shallow landslides in an alpine catchment (Urseren Valley, Switzerland). Nat. Hazards Earth Syst. Sci. 2008, 8, 509-520. [CrossRef]

17. Reichenbach, P.; Busca, C.; Mondini, A.C.; Rossi, M. Land use change scenarios and landslide susceptibility zonation: The Briga Catchment Test Area (Messina, Italy). In Engineering Geology for Society and Territory; Lollino, G., Manconi, A., Clague, J., Eds.; Springer International Publishing: Berlin/Heidelberg, Germany, 2015; Volume 1, pp. 557-561.

18. Schuster, R.; Highland, L. The Third Hans Cloos Lecture. Urban landslides: Socioeconomic impacts and overview of mitigative strategies. Bull. Eng. Geol. Environ. 2007, 66, 1-27. [CrossRef]

19. Geertsema, M.; Pojar, J.J. The influnce of landslides on biophysical diversity-A perspective from British Columbia. Geomorphology 2007, 89, 55-69. [CrossRef]

20. Ives, J.D.; Messerli, B. The Himalayan Dilemma: Reconciling Development and Conservation; Routledge: London, UK, $1989 ;$ p. 7.

21. NDMA. Management of Landslides and Snow Avalanches; National Disaster Management Authority (NDMA), Government of India: New Delhi, India, 2009.

22. Sarkar, S. Landslides in Darjiling Himalayas. Trans. Jpn. Geomorphol. Union. 1999, 20, $299-315$.

23. Rautela, P.; Rakshit, R.; Jha, V.K.; Gupta, R.K.; Munsi, A. GIS and remote sensing-based study of the reservoir-induced landuse/land-cover changes in the catchment of Tehri dam in Garhwal Himalaya, Uttarakhand (India). Curr. Sci. 2002, 83, 308-311.

24. Saha, A.K.; Gupta, R.P.; Arora, M.K. GIS based landslide hazard zonation in the Bhagirathi (Ganga) Valley, Himalaya. Int. J. Remote Sens. 2002, 23, 357-369. [CrossRef] 
25. Sarkar, S.; Kanungo, D.P.; Patra, A.K. Landslides in the Alaknanda Valley of Garhwal Himalaya. Q. J. Eng. Geol. Hydrogeol. 2005, 39, 79-82. [CrossRef]

26. Anbalagan, R. Landslide hazard evaluation and zonation mapping in mountainous terrain. Eng. Geol. 1992, 32, 269-277. [CrossRef]

27. Pauchauri, A.K.; Pant, M. Landslide hazard mapping based on geological attributes. Eng. Geol. 1992, 32, 81-100. [CrossRef]

28. Dai, F.C.; Lee, C.F. Frequency-volume relation and prediction of rainfall-induced landslides. Eng. Geol. 2001, 9, 253-266. [CrossRef]

29. Gunther, A.; Thiel, C. Combined rock slope stability and shallow landslide susceptibility assessment of the Jasmund Cliff area (Ru“"gen Island, Germany). Nat. Hazards Earth Syst. Sci. 2009, 9, 687-698. [CrossRef]

30. Hasegawa, S.; Dahal, R.K.; Nishimura, T.; Nonomura, A.; Yamanaka, M. DEM-based analysis of earthquake-induced shallow landslide susceptibility. Geotech. Geol. Eng. 2009, 27, 419-430. [CrossRef]

31. Mavrouli, O.; Corominas, J.; Wartman, J. Methodology to evaluate rock slope stability under seismic conditions at Sola' de Santa Coloma, Andorra. Nat. Hazards Earth Syst. Sci. 2009, 9, 1763-1773. [CrossRef]

32. Van Westen, C.J.; Rengers, N.; Soeters, R. Use of geomorphological information in indirect landslide susceptibility assessment. Nat. Hazards 2003, 30, 399-419. [CrossRef]

33. Pradhan, B.; Youssef, A.M. Manifestation of remote sensing data and GIS on landslide hazard analysis using spatial-based statistical models. Arab. J. Geosci. 2009, 3, 319-326. [CrossRef]

34. Oh, H.J.; Lee, S.; Hong, M. Landslide Susceptibility Assessment Using Frequency Ratio Technique with Iterative Random Sampling. J. Sens. 2017, 2017, 1-22. [CrossRef]

35. Ayalew, L.; Yamagishi, H.; Marui, H.; Kanno, T. Landslides in Sado Island of Japan: Part II. GIS-based susceptibility mapping with comparison of results from two methods and verifications. Eng. Geol. 2005, 81, 432-445. [CrossRef]

36. Wu, W.; Sidle, R.C. A distributed slope stability model for steep forested basins. Water Resour. Res. 1995, 31, 2097-2110. [CrossRef]

37. Pack, R.; Tarboton, D.; Goodwin, C. The SINMAP approach to terrain stability mapping. In Proceedings of the 8th Congress of the International Association of Engineering Geology, Vancouver, BC, Canada, 21-25 September 1998.

38. Ewen, J.; Parkin, G.; O'Connell, P.E. SHETRAN: Distributed river basin flow and transport modeling system. J. Hydrol. Eng. 2000, 5, 250-258. [CrossRef]

39. Baum, R.L.; Savage, W.Z.; Godt, J.W. TRIGRS—A Fortran program for transient rainfall infiltration and grid-based regional slope-stability analysis. US Geol. Surv. Open-File Rep. 2002, 424, 38.

40. Simoni, S.; Zanotti, F.; Bertoldi, G.; Rigon, R. Modelling the probability of occurrence of shallow landslides and channelized debris flows using GEOtop-FS. Hydrol. Process. 2008, 22, 532-545. [CrossRef]

41. Kim, D.; Im, S.; Lee, S.H.; Hong, Y.; Cha, K.S. Predicting the Rainfall-Triggered Landslides in a Forested Mountain Region Using TRIGRS Model. J. Mountain. Sci. 2010, 7, 83-91. [CrossRef]

42. Park, D.W.; Nikhil, N.V.; Lee, S.R. Landslide and debris flow susceptibility zonation using TRIGRS for the 2011 Seoul landslide event. Nat. Hazards Earth Syst. Sci. 2013, 13, 2833-2849. [CrossRef]

43. Montgomery, D.R.; Dietrich, W.E. A physically based model for the topographic control on shallow landsliding. Water Resour. Res. 1994, 30, 1153-1171. [CrossRef]

44. Carrara, A.; Cardinali, M.; Guzzetti, F.; Reichenbach, P. GIS technology in mapping landslide hazard. In Geographical Information Systems in Assessing Natural Hazards; Springer: Dordrecht, The Netherlands, 1995; pp. 135-175.

45. Paulin, L.G.; Bursik, M.I. A tool for multimethod, multiple soil layers slope stability analysis. Comput. Geosci. 2009, 35, 1007-1016. [CrossRef]

46. Yoshimatsu, H.; Abe, S. A review of landslide hazards in Japan and assessment of their susceptibility using an analytical hierarchic process (AHP) method. Landslides 2006, 3, 149-158. [CrossRef]

47. Castellanos, A.; Enrique, A.; Van Westen, C.J. Qualitative landslide susceptibility assessment by multicriteria analysis: A case study from San Antonio del Sur, Guantanamo, Cuba. Geomorphology 2008, 94, 453-466. [CrossRef]

48. Van Westen, C.J.; Rengers, N.; Terlien, M.T.J. Prediction of the occurrence of slope instability phenomena through GIS-based hazard zonation. Geol. Rundsch 1997, 86, 4004-4414.

49. Van Westen, C.J.; van Asch, T.W.J.; Soeters, R. Landslide hazard and risk zonation-Why is it still so difficult? Bull. Eng. Geol. Environ. 2006, 65, 167-184. [CrossRef]

50. Fall, M.; Azam, R.; Noubactep, C. A multi-method approach to study the stability of natural slopes and landslide susceptibility mapping. Eng. Geol. 2006, 82, 241-263. [CrossRef]

51. Lee, S.; Min, K. Statistical analysis of landslide susceptibility at Yongin, Korea. Environ. Geol. 2001, 40, 1095-1113. [CrossRef]

52. Sarkar, S.; Kanungo, D.P. An integrated approach for landslide susceptibility mapping using remote sensing and GIS. Photogramm. Eng. Remote Sens. 2004, 70, 617-625. [CrossRef]

53. Lee, S.; Choi, J.; Min, K. Probabilistic landslide hazard mapping using GIS and remote sensing data at Boun, Korea. Int. J. Remote Sens. 2004, 25, 2037-2052. [CrossRef]

54. Pan, X.; Nakamura, H.; Nozaki, T.; Huang, X. A GIS-based landslide hazard assessment by multivariate analysis. Landslides J. Jpn. Landslide Soc. 2008, 45, 187-195. [CrossRef]

55. Pradhan, B. Landslide Susceptibility mapping of a catchment area using frequency ratio, fuzzy logic and multivariate logistic regression approaches. J. Indian Soc. Remote Sens. 2010, 38, 301-320. [CrossRef] 
56. Hong, H.; Pourghasemi, H.R.; Pourtaghi, Z.S. Landslide susceptibility assessment in Lianhua County (China): A comparison between a random forest data mining technique and bivariate and multivariate statistical models. Geomorphology 2016, 259, 105-118. [CrossRef]

57. Bai, S.B.; Wang, J.; Lü, G.N.; Zhou, P.G.; Hou, S.S.; Xu, S.N. GIS-based logistic regression for landslide susceptibility mapping of the Zhongxian segment in the Three Gorges area, China. Geomorphology 2010, 115, 23-31. [CrossRef]

58. Das, I.; Stein, A.; Kerle, N.; Dadhwal, V.K. Landslide susceptibility mapping along road corridors in the Indian Himalayas using Bayesian logistic regression models. Geomorphology 2012, 179, 116-125. [CrossRef]

59. Wang, L.J.; Kazuhide, S.; Shuji, M. Landslide susceptibility analysis with logistic regression model based On FCM sampling strategy. Comput. Geosci. 2013, 57, 81-92. [CrossRef]

60. Poudyal, C.P.; Chang, C.; Oh, H.J.; Lee, S. Landslide susceptibility maps comparing frequency ratio and artificial neural networks: A case study from the Nepal Himalaya. Environ. Earth Sci. 2010, 61, 1049-1064. [CrossRef]

61. Bui, D.T.; Pradhan, B.; Lorfman, O.; Revhaug, I.; Dick, O.B. Landslide susceptibility assessment in the Hoa Binh province of Vietnam: A comparison of the Levenberg-Marquardt and Bayesian regularized neural networks. Geomorphology 2012, 171, 12-29.

62. Choi, J.; Oh, H.J.; Lee, H.J.; Lee, C.; Lee, S. Combining landslide susceptibility maps obtained from frequency ratio, logistic regression, and artificial neural network models using ASTER images and GIS. Eng. Geol. 2011, 124, 12-23. [CrossRef]

63. Park, S.; Choi, C.; Kim, B.; Kim, J. Landslide susceptibility mapping using frequency ratio, analytic hierarchy process, logistic regression, and artificial neural network methods at the Inje area, Korea. Environ. Earth Sci. 2012, 68, 1443-1464. [CrossRef]

64. Pradhan, B.; Oh, H.J.; Buchroithner, M. Weights-of-evidence model applied to landslide susceptibility mapping in a tropical hilly area. Geomat. Nat. Hazards Risk 2010, 1, 199-223. [CrossRef]

65. Regmi, N.R.; Giardino, J.R.; Vitek, J.D. Modeling susceptibility to landslides using the weight of evidence approach: Western Colorado, USA. Geomorphology 2010, 115, 172-187. [CrossRef]

66. Armas, I. Weights of evidence method for landslide susceptibility mapping. Prahova Subcarpathians, Romania. Nat. Hazards 2012, 60, 937-950. [CrossRef]

67. Nandi, A.; Shakoor, A. A GIS-based landslide susceptibility evaluation using bivariate and multivariate statistical analyses. Eng. Geol. 2010, 110, 11-20. [CrossRef]

68. Mohammady, M.; Pourghasemi, H.R.; Pradhan, B. Landslide susceptibility mapping at Golestan Province, Iran: A comparison between frequency ratio, Dempster-Shafer, and weights-of-evidence models. J. Asian Earth Sci. 2012, 61, 221-236. [CrossRef]

69. Corominas, J.; van Westen, C.; Frattini, P.; Cascini, L.; Malet, J.-P.; Fotopoulou, S.; Catani, F.; van den Eeckhaut, M.; Mavrouli, O.; Agliardi, F.; et al. Recommendations for the quantitative analysis of landslide risk. Bull. Eng. Geol. Environ. 2014, 73, 209-263. [CrossRef]

70. Strauch, R.; Istanbulluoglu, E.; Riedel, J. A new approach to mapping landslide hazards: A probabilistic integration of empirical and physically based models in the North Cascades of Washington, USA. Nat. Hazards Earth Syst. Sci. 2019, 19, $2477-2495$. [CrossRef]

71. Oh, H.-J.; Pradhan, B. Application of a neuro-fuzzy model to landslide-susceptibility mapping for shallow landslides in a tropical hilly area. Comput. Geosci. 2011, 37, 1264-1276. [CrossRef]

72. Xu, C.; Dai, F.; Xu, X.; Lee, Y.H. GIS-based support vector machine modeling of earthquake-triggered landslide susceptibility in the Jianjiang River watershed, China. Geomorphology 2012, 145, 70-80. [CrossRef]

73. Hong, H.; Pradhan, B.; Xu, C.; Bui, D.T. Spatial prediction of landslide hazard at the Yihuang area (China) using two-class kernel logistic regression, alternating decision tree and support vector machines. Catena 2015, 133, 266-281. [CrossRef]

74. Saito, H.; Nakayama, D.; Matsuyama, H. Comparison of landslide susceptibility based on a decision-tree model and actual landslide occurrence: The Akaishi Mountains, Japan. Geomorphology 2009, 109, 108-121. [CrossRef]

75. Tian, Y.; Xu, C.; Hong, H.; Zhou, Q.; Wang, D. Mapping earthquake-triggered landslide susceptibility by use of artificial neural network (ann) models: An example of the 2013 Minxian (China) mw 5.9 event. Geomat. Nat. Hazards Risk 2019, 10, 1-25. [CrossRef]

76. Aghdam, I.N.; Pradhan, B.; Panahi, M. Landslide susceptibility assessment using a novel hybrid model of statistical bivariate methods (FR and WOE) and adaptive neuro-fuzzy inference system (ANFIS) at southern Zagros Mountains in Iran. Environ. Earth Sci. 2017, 76, 237. [CrossRef]

77. Chen, B.; Tian, Z.; Chen, Z.-S.; Zhang, Z.-C.; Sun, W. Structural safety evaluation of in-service tunnels using an adaptive neuro-fuzzy inference system. J. Aerosp. Eng. 2018, 31, 5. [CrossRef]

78. Freun, Y.; Schapire, R.E. A decision-theoretic generalization of on-line learning and an application to boosting. J. Comput. Syst. Sci. 1997, 55, 119-139. [CrossRef]

79. Micheletti, N.; Foresti, L.; Robert, S.; Leuenberger, M.; Pedrazzini, A.; Jaboyedoff, M.; Kanevski, M. Machine learning feature selection methods for landslide susceptibility mapping. Math. Geol. 2014, 46, 33-57. [CrossRef]

80. Sun, D.; Xu, J.; Wen, H.; Wang, D. Assessment of landslide susceptibility mapping based on Bayesian hyperparameter optimization: A comparison between logistic regression and random forest. Eng. Geol. 2020, 281, 105972. [CrossRef]

81. Bui, D.T.; Tuan, T.A.; Klempe, H.; Pradhan, B.; Revhaug, I. Spatial prediction models for shallow landslide hazards: A comparative assessment of the efficacy of support vector machines, artificial neural networks, kernel logistic regression, and logistic model tree. Landslides 2016, 13, 361-378.

82. Tsangaratos, P.; Ilia, I. Comparison of a logistic regression and Naïve Bayes classifier in landslide susceptibility assessments: The influence of models complexity and training dataset size. Catena 2016, 145, 164-179. [CrossRef] 
83. Zhang, T.; Han, L.; Han, J.; Li, X.; Zhang, H.; Wang, H. Assessment of Landslide Susceptibility Using Integrated Ensemble Fractal Dimension with Kernel Logistic Regression Model. Entropy 2019, 21, 218. [CrossRef]

84. Chen, W.; Xie, X.; Wang, J.; Pradhan, B.; Hong, H.; Tien Bui, D.; Duan, Z.; Ma, J. A comparative study of logistic model tree, random forest, and classification and regression tree models for spatial prediction of landslide susceptibility. Catena 2017, 151, 147-160. [CrossRef]

85. Li, X.; Wang, Y. Applying various algorithms for species distribution modelling. Integr. Zool. 2013, 8, 124-135. [CrossRef] [PubMed]

86. Felicisimo, A.; Cuartero, A.; Remondo, J.; and Quiros, E. Mapping landslide susceptibility with logistic regression, multiple adaptive regression splines, classification and regression trees, and maximum entropy methods: A comparative study. Landslides 2013, 10, 175-189. [CrossRef]

87. Chen, W.; Sun, Z.; Han, J. Landslide susceptibility modeling using integrated ensemble weights of evidence with logistic regression and random forest models. Appl. Sci. 2019, 9, 171. [CrossRef]

88. He, Q.; Shahabi, H.; Shirzadi, A.; Li, S.; Chen, W.; Wang, N.; Chai, H.; Bian, H.; Ma, J.; Chen, Y.; et al. Landslide spatial modelling using novel bivariate statistical based Naïve Bayes, RBF Classifier, and RBF Network machine learning algorithms. Sci. Total Environ. 2019, 663, 1-15. [CrossRef]

89. Goetz, J.; Brenning, A.; Petschko, H.; Leopold, P. Evaluating machine learning and statistical prediction techniques for landslide susceptibility modeling. Comput. Geosci. 2015, 81, 1-11. [CrossRef]

90. Pourghasemi, H.R.; Rahmati, O. Prediction of the landslide susceptibility: Which algorithm, which precision? Catena 2018, 162, 177-192. [CrossRef]

91. Majumder, N. Distribution and intensity of landslide processes in North Eastern India A zonation map thereof. In Proceedings of the Third International Symposium on Landslides, New Delhi, India, 7-11 April 1980; Sarita Prakashan: Meerut, India, 1980; Volume 1.

92. Gupta, R.P.; Joshi, B.C. Landslide hazard zonation using the GIS approach-A case study from the Ramganga catchment, Himalayas. Eng. Geol. 1990, 28, 119-131. [CrossRef]

93. BIS. Preparation of Landslide Hazard Zonation Maps in Mountainous Terrains-Guidelines, Bureau of Indian Standards IS 14496 (Part-2); Government of India: New Delhi, India, 1998.

94. Jaiswal, P. Landslide Susceptibility Mapping based on GIS \& Modified BIS Code Appraisal. J. Eng. Geol. 2006, 1, 65-72.

95. Martha, T.R.; van Westen, C.J.; Kerle, N.; Jetten, V.; Kumar, V. Landslide hazard and risk assessment using semi-automatically created landslide inventories. Geomorphology 2013, 184, 139-150. [CrossRef]

96. Ghosh, S.; van Westen, C.J.; Carranza, E.J.M.; Ghoshal, T.; Sarkar, N.; Surendranath, M. A quantitative approach for improving the BIS (Indian) method of medium-scale landslide susceptibility. J. Geol. Soc. India 2009, 74, 625-638. [CrossRef]

97. Pachauri, A.K.; Gupta, P.V.; Chander, R. Landslide zoning in a part of the Garhwal Himalayas. Environ Geol. 1998, 36, 325-334. [CrossRef]

98. Gupta, V.; Ahmed, I. Geotechnical characteristics of Surabhi Resort landslide in Mussoorie, Garhwal Himalaya, India. Himal. Geol. 2007, 28, 21-32.

99. Asthana, A.K.L.; Sah, M.P. Landslides and cloudbursts in the Mandakini Basin of Garhwal Himalaya. Himal. Geol. 2007, 28 , 59-67.

100. Mathew, J.; Jha, V.K.; Rawat, G.S. Weights of evidence modeling for landslide hazard zonation mapping in part of Bhagirathi valley, Uttarakhand. Curr. Sci. 2007, 92, 628-638.

101. Mathew, J.; Jha, V.K.; Rawat, G.S. Application of binary logistic regression analysis and its validation for landslide susceptibility mapping in part of Garhwal Himalaya, India. Int. J. Remote Sens. 2007, 28, 2257-2275. [CrossRef]

102. Pandey, A.; Dabral, P.P.; Chowdary, V.M.; Yadav, N.K. Landslide hazard zonation using remote sensing and GIS: A case study of Dikrong river basin, Arunachal Pradesh, India. Environ. Geol. 2008, 54, 1517-1529. [CrossRef]

103. Sharma, M.; Kumar, R. GIS-based landslide hazard zonation: A case study from the Parwanoo area, lesser and outer Himalaya, HP, India. Bull. Eng. Geol. Environ. 2008, 67, 129-137. [CrossRef]

104. Martha, T.R.; Kerle, N.; Jetten, V.; van Westen, C.J.; Kumar, K.V. Characterizing spectral, spatial and morphometric properties of landslides for semi-automatic detection using object-oriented methods. Geomorphology 2010, 116, 24-36. [CrossRef]

105. Das, I.; Sahoo, S.; Van Westen, C.; Stein, A.; Hack, R. Landslide susceptibility assessment using logistic regression and its comparison with a rock mass classification system, along a road section in the northern Himalayas (India). Geomorphology 2010, 114, 627-637. [CrossRef]

106. Martha, T.R.; Roy, P.; Govindharaj, K.B.; Kumar, K.V.; Diwakar, P.; Dadhwal, V. Landslides triggered by the june 2013 extreme rainfall event in parts of Uttarakhand state, India. Landslides 2015, 12, 135-146. [CrossRef]

107. Pandey, V.K.; Pourghasemi, H.R.; Sharma, M.C. Landslide susceptibility mapping using maximum entropy and support vector machine models along the highway corridor, Garhwal Himalaya. Geocarto Int. 2018, 35, 168-187. [CrossRef]

108. Banerjee, P.; Ghose, M.K.; Pradhan, R. Analytic hierarchy process and information value method-based landslide susceptibility mapping and vehicle vulnerability assessment along a highway in Sikkim Himalaya. Arab. J. Geosci. 2018, 11, 139. [CrossRef]

109. Maheshwari, B.K. Earthquake-induced landslide hazard assessment of chamoli district, uttarakhand using relative frequency ratio method. Indian Geotech. J. 2019, 49, 108-123.

110. Kumar, R.; Anbalagan, R. Landslide susceptibility mapping of the Tehri reservoir rim area using the weights of evidence method. J. Earth Syst. Sci. 2019, 128, 153. [CrossRef] 
111. Kannan, M.; Saranathan, E.; Anbalagan, R. Comparative analysis in GIS-based landslide hazard zonation—a case study in Bodi-Bodimettu Ghat section, Theni District, Tamil Nadu. India. Arab. J. Geosci. 2015, 8, 691-699. [CrossRef]

112. Kala, C.P. Deluge, disaster and development in Uttarakhand Himalayan region of India: Challenges and lessons for disaster management. Int. J. Disaster Risk Reduct. 2014, 8, 143-152. [CrossRef]

113. Naithani, A.K. The August 1998 Okhimath tragedy in Rudraprayag district of Garhwal Himalaya, Uttaranchal, India. GAIA 2001, $16,145-156$.

114. Naithani, A.K.; Kumar, D.; Prasad, C. The catastrophic landslide of 16 July 2001 in Phata Byung area, Rudrapryag district, Garhwal Himalaya, India. Curr. Sci. 2002, 82, 921-923.

115. National Remote Sensing Centre (NRSC). Report on Okhimath Landslides in 2012-Satellite Based Study; National Remote Sensing Centre (NRSC): Hyderabad, India, 2012.

116. National Remote Sensing Cente (NRSC). Report on Uttarakhand Landslides-2013: Satellite-Based Study. National Remote; National Remote Sensing Centre (NRSC): Hyderabad, India, 2013.

117. Rautela, P.; Sajwan, K.S.; Khanduri, S.; Ghildiyal, S.; Rawat, C.; Rawat, A. Geological Investigations in Rudraprayag District with Special Reference to Mass Instability; Disaster Mitigation and Management Center (DMMC): Dehradun, India, 2014.

118. Naithani, A.K.; Rawat, G.S.; Nawani, P.C. Investigation of landslide events on 12th July 2007 due to cloudburst in Chamoli district, Uttarakhand, India. Int. J. Earth Sci. Eng. 2011, 4, 777-786.

119. Rawat, M.S.; Uniyal, D.P.; Dobhal, R.; Joshi, V.; Rawat, B.S.; Bartwal, A.; Singh, D.; Aswal, A. Study of landslide hazard zonation in Mandakini Valley, Rudraprayag district, Uttarakhand using remote sensing and GIS. Curr. Sci. 2015, 109, 158-170.

120. Rana, N.; Bisht, P.; Bagri, D.S.; Wasson, R.J.; Sundriyal, Y. Identification of landslide-prone zones in the geomorphically and climatically sensitive Mandakini valley, (central Himalaya), for disaster governance using Weights of Evidence method. Geomorphology 2017, 284, 41-52.

121. Kumar, G.; Agrawal, N.C. Geology of the Srinagar-Nandprayag Area (Alakananda Valley), Chamoli, Garhwaland Tehri Garhwal Districts, Kumaun Himalaya, Uttar Pradesh. Himal. Geol. 1975, 5, $29-59$.

122. Kumar, G. Geology of Uttar Pradesh and Uttaranchal; Geological Society of India: Bangalore, India, 2005.

123. Van Westen, C.J.; Castellanos, E.; Kuriakose, S.L. Spatial data for landslide susceptibility, hazard, and vulnerability assessment: An overview. Eng. Geol. 2008, 102, 112-131. [CrossRef]

124. Guzzetti, F.; Mondini, A.C.; Cardinali, M.; Fiorucci, F.; Santangelo, M.; Chang, K.-T. Landslide inventory maps: New tools for an old problem. Earth-Sci. Rev. 2012, 112, 42-66. [CrossRef]

125. Mohammadi, A.; Shahabi, H.; Bin Ahmad, B. Integration of insartechnique, google earth images and extensive field survey for landslide inventory in a part of Cameron highlands, Pahang, Malaysia. Appl. Ecol. Environ. Res. 2007, 16, 8075-8091. [CrossRef]

126. Sato, H.; Harp, E. Interpretation of earthquake-induced landslides triggered by the 12 May 2008, M7. 9 Wenchuan earthquake in the Beichuan area, Sichuan Province, China using satellite imagery and Google Earth. Landslides 2009, 6, 153-159. [CrossRef]

127. Ayalew, L.; Yamagishi, H. The application of GIS-based logistic regression for landslide susceptibility mapping in the KakudaYahiko Mountains, Central Japan. Geomorphology 2005, 65, 15-31. [CrossRef]

128. Bonham-Carter, G.F.; Agterberg, F.P.; Wright, D.F. Weights of evidence modelling: A new approach to mapping mineral potential. Stat. Appl. Earth Sci. 1989, 89, 171-183.

129. Bonham-Carter, G.F. Geographic information systems for geoscientist: Modelling with GIS. In Computer Methods in the Geosciences; Merriam, D.F., Ed.; Pergamon/Elsevier: New York, NY, USA, 2002; Volume 13, pp. 302-334.

130. Ding, Q.; Chen, W.; Hong, H. Application of frequency ratio, weights of evidence and evidential belief function models in landslide susceptibility mapping. Geocarto Int. 2017, 32, 619-639. [CrossRef]

131. Sifa, S.F.; Mahmud, T.; Tarin, M.A.; Haque, D.M.E. Event-based landslide susceptibility mapping using weights of evidence (WoE) and modified frequency ratio (MFR) model: A case study of Rangamati district in Bangladesh. Geol. Ecol. Landsc. 2019, 4, 222-235. [CrossRef]

132. Bonham-Carter, G.F. Geographic information systems for geoscientists: Modeling with GIS. In Computer Methods in the Geosciences; Bonham-Carter, F., Ed.; Pergamon: Oxford, UK, 1994; p. 398. Available online: https://www.sciencedirect.com/book/97800804 18674/geographic-information-systems-for-geoscientists (accessed on 17 November 2020).

133. Yesilnacar, E.; Topal, T. Landslide susceptibility mapping: A comparison of logistic regression and neural networks methods in a medium scale study, Hendek region (Turkey). Eng. Geol. 2005, 79, 251-266. [CrossRef]

134. Magliulo, P.; Di, L.A.; Russo, F.; Zelano, A. Geomorphology and landslide susceptibility assessment using GIS and bivariate statistics: A case study in southern Italy. Nat Hazards 2008, 47, 411. [CrossRef]

135. Fawcett, T. An introduction to roc analysis. Pattern Recognit. Lett. 2006, 27, 861-874. [CrossRef]

136. Samia, J.; Temme, A.; Bregt, A.K.; Wallinga, J.; Stuiver, J.; Guzzetti, F.; Ardizzone, F.; Rossi, M. Implementing landslide path dependency in landslide susceptibility modelling. Landslides 2018, 15, 2129-2144. [CrossRef] 